\title{
THE ORIGIN OF GLACIAL ALPINE LANDSCAPE IN TRÖLLASKAGI PENINSULA (NORTH ICELAND)
}

\author{
N. ANDRÉS*, L.M. TANARRO, J.M. FERNÁNDEZ, D. PALACIOS \\ Research Group of High Mountain Physical Geography, Departamento de Análisis Geográfico \\ Regional y Geografía Física, Universidad Complutense de Madrid, Spain
}

\begin{abstract}
The Tröllaskagi Peninsula is located in north central Iceland, between meridians 19 $30^{\prime} \mathrm{W}$ and $18^{\circ} 10^{\prime} \mathrm{W}$, limited by Skagafjödur fiord to the west and the Eyjafjödur fiord to the east, jutting out into the North Atlantic to latitude $66^{\circ} 12^{\prime} \mathrm{N}$ and linked to the central Icelandic highlands to the south. The Peninsula is a Tertiary basalt plateau topped by flat summits with altitudes of 1000-1500 m, intensely dissected by the drainage network. The aim of this present study is to synthesize the recent advances in our understanding of the landscape and its dynamics in the Tröllaskagi Peninsula and find the origin of its significant difference from the rest of Iceland. Results of the most recent research suggest the situation of Tröllaskagi as ice-free, delimited by the two great glacial outlets flowing down from the Icelandic Ice Sheet through the Skagafjödur and Eyjafjödur fiords, from at least the Oldest Dryas to the end of the Early Preboreal. Inland in Tröllaskagi, the glaciers formed in the north-facing cirques without losing their alpine characteristics during the Late Pleistocene and Holocene. The advances of these glaciers during the Oldest, Older and Youngest Dryas and the Early Preboreal were only a few hundred metres greater than the most important advance in the second half of the Holocene, during the Little Ice Age. Only a few of these glaciers remained debris-free and are sensitive to the minor climate oscillations. The rest, due to the important geomorphological activity on their walls, developed into debris-covered and rock glaciers and lost this significant dynamism.
\end{abstract}

\section{Origen del paisaje glacial alpino en la Península de Tröllaskagi (Norte de Islandia)}

RESUMEN. La Peninsula de Tröllaskagi se localiza en el Norte de Islandia Central, entre los meridianos $19^{\circ} 30^{\prime} \mathrm{W}$ y $18^{\circ} 10^{\prime} \mathrm{W}$. Está delimitada al oeste por el fiordo de Skagafjödur y al este por el fiordo de Eyjafjödur. Al norte, se adentra en el oceano Nor-Atlántico hasta el paralelo $66^{\circ} 12^{\prime} \mathrm{N}$ y, al sur, enlaza con las altas mesetas de Islandia Central. La peninsula es, en realidad, una gran meseta formada por el apilamiento de lavas basálticas terciarias, con cumbres aplanadas, entre 1000 y 1500 metros de altitud, cuyo relieve ha sido intensamente disectado por la red de drenaje. El objetivo de este trabajo es resumir el conocimiento ac- 
tual sobre el paisaje de la Península Tröllaskagi y su dinámica, y buscar el origen de su diferencia con el resto de Islandia. Los resultados de las investigaciones defienden una situación de la Península de Tröllaskagi libre de hielo en gran parte, delimitada por grandes lenguas de hielo que descendían desde el inlandsis del Centro de Islandia por los fiordos Skagafjödur y Eyjafjödur, al menos desde el Oldest Dryas hasta el final del periodo Preboreal Temprano. Sin embargo, en el interior de Tröllaskagi, los glaciares sólo ocuparon las cabeceras de los circos que miraban al norte, sin perder su carácter alpino durante el Pleistoceno Tardio y el Holoceno. Los avances de estos glaciares en el Oldest, Older, y Younger Dryas y Preboreal Temprano fueron sólo de un centenar de metros mayores que los del máximo avance de la segunda mitad del Holoceno (Pequeña Edad de Hielo). Sólo unos pocos de estos glaciares permanecieron sin cubierta de derrubios y por ello son muy sensibles a las pequeñas osclaciones del clima. El resto de los glaciares, a causa de la gran actividad geomorfológica de las paredes de los circos, se transformaron en glaciares cubiertos y glaciares rocosos y han perdido su gran dinamismo.

Key words: Iceland, Tröllaskagi Peninsula, deglaciation, Late Pleistocene, Holocene, rock glacier.

Palabras clave: Islandia, Península de Trollaskagi, deglaciación, Pleistoceno tardío, Holoceno, glaciares rocosos.

Received 15 January 2016

Accepted 15 February 2016

*Corresponding author: Research Group of High Mountain Physical Geography. Departamento de Análisis Geográfico Regional y Geografía Física, Universidad Complutense de Madrid, Madrid, 28040 Madrid, Spain E-mail: nandresp@ucm.es

\section{Introduction}

The Tröllaskagi Peninsula is located in north central Iceland, between $19^{\circ} 30^{\prime} \mathrm{W}$ and $18^{\circ} 10^{\prime} \mathrm{W}$, jutting out into the North Atlantic to latitude $66^{\circ} 12^{\prime} \mathrm{N}$ and linked to the central Icelandic highlands to the south (Fig. 1). The Peninsula is a Tertiary basalt plateau topped by flat summits with altitudes of $1000-1500 \mathrm{~m}$, intensely dissected by the drainage network. 


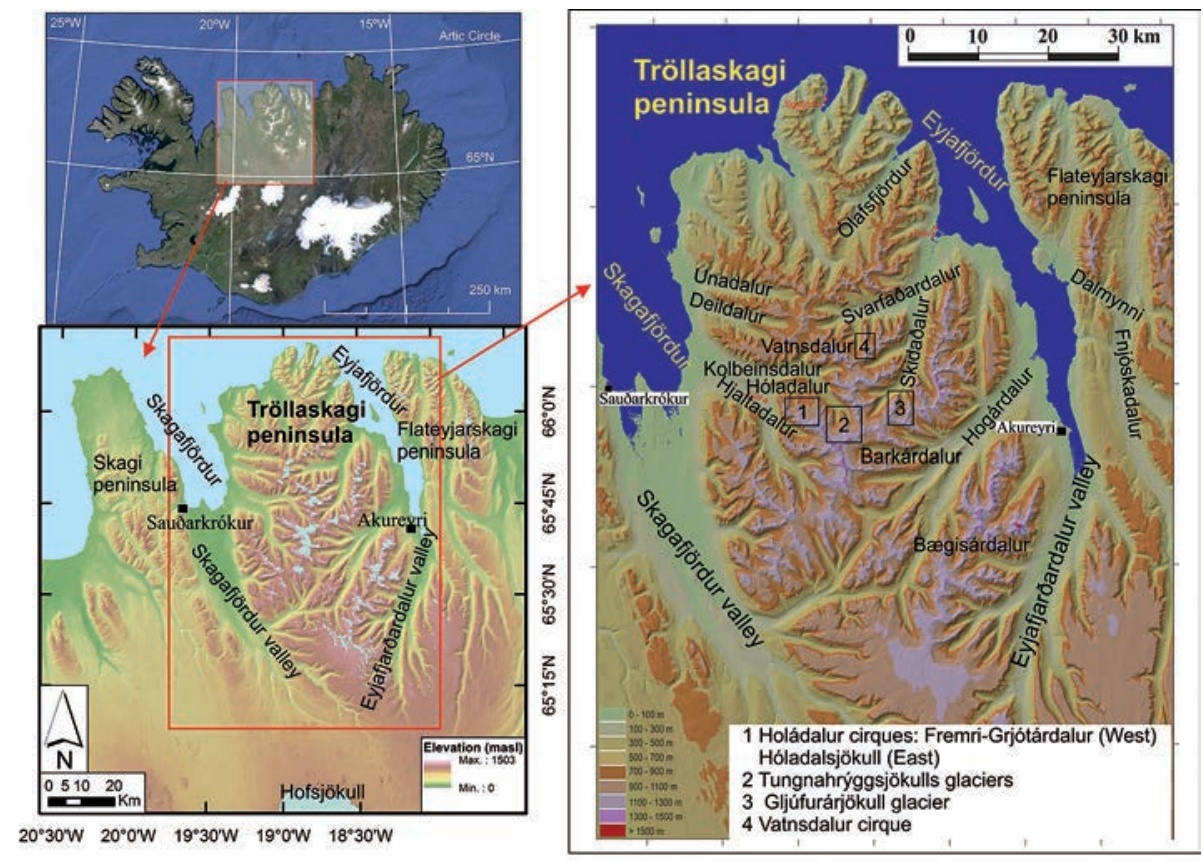

Figure 1. Location of the Tröllaskagi Peninsula and of the main geographic elements cited in the text.

The landscape of the Tröllaskagi Peninsula is remarkably different from the rest of Iceland, not only because of the absence of recent volcanic activity, but also because of the predominanance of numerous alpine cirques, with a total of 167 small glaciers, a few of which are debris-free glaciers and the rest are debris-covered and rock glaciers. This is the highest concentration of this type of glacier and practically the only area of Iceland where rock glaciers exist. Early research into the landscape of this Peninsula highlighted its different characteristics compared with the rest of Iceland (Thórarinsson, 1937) because of its marked topographical contrasts, the intensity of the slope processes, the predominance of corrie-type glaciers and the absence of current and recent ice-caps. Sigbjarnasson (1983) introduced the term "alpine" to define this landscape. In contrast, in the south and centre of the island, ice-caps and landforms derived from the deglaciation of the ice-sheet predominate. Therefore, one of the first criteria to be analysed here is the relationship between this Peninsula and the glaciation and deglaciation of the Iceland.

In fact, during the Last Glacial Maximum (LGM), Iceland was covered by the Icelandic Ice Sheet (IIS), with approximately $2 \mathrm{~km}$ ice thickness in its centre (Hubbard et $a l ., 2006)$ and its termini reached the shelf edge, $40 \mathrm{~km}$ from the present coast line in the north, by $24.4 \mathrm{ka}$ (Pétursson et al., 2015). The evolution of the IIS has been summarised in recent publications (Kaldal and Víkingssson, 1990; Norðdahl and Pétursson 2005; Norðdahl et al., 2008; Geirsdóttir et al., 2009; Geirsdóttir, 2011; Pétursson et al., 2015). Most of these publications highlight the fact that the IIS retreated rapidly and 
catastrophically, until it occupied only the centre and southeast of the island, around 15 ka (Andrews et al., 2000; Norðdahl and Einarsson 2001, Geirsdóttir et al. 2009, Brynjólfsson et al., 2015a). At the end of the Bølling stadial there was a short glacial advance in the Older Dryas (Ingólfsson et al., 1997). During the Allerød stadial, the temperature rose again considerably and the glaciers retreated again (Rundgren, 1995, 1999; Rundgren and Ingólfsson, 1999). During the Younger Dryas the glaciers started to re-advance and in the north and northwest they reached the present coastline and entered the great fiords, in many cases obstructing lateral valleys and forming lakes (Geirsdóttir et al., 2002; Norðdahl and Pétursson, 2005), but many interfluves remained free of ice during this period (Norðdahl and Einarsson, 2001). After the glacier retreat at the end of the Younger Dryas, the glacial fronts re-advanced again in the Early Preboreal period, around 11.2 ka (Ingólfsson et al., 1997; Norðdahl and Einarsson, 2001; Norðdahl and Pétursson, 2005). Later, the glaciers retreated rapidly (Kaldal and Víkingssson, 1990; Andrews et al., 2000; Norðdahl and Einarsson, 2001; Geirsdóttir et al., 2002, 2009; Larsen et al., 2012). By 10.2 ka the centre and north of Iceland was already deglaciated (Stötter et al., 1999; Caseldine et al., 2003). Finally, by 8.7 ka the IIS had definitively disappeared and the extent of the glaciers was similar to or less than at present (Pétursson et al., 2015). Between 8 and $5 \mathrm{ka}$, in what is known as the Holocene Thermal Maximum, some of the great current glaciers disappeared from the centre of Iceland (Caseldine et al., 2003, 2006, Geirsdóttir et al., 2009, 2013). After 5 ka, there was a trend to cooling which accelerated at $3 \mathrm{ka}$ (Geirsdóttir et al., 2009, 2013). The greatest neoglacial advance of the ice-cap glaciers in the centre of Iceland was during the Little Ice Age (LIA), when the Holocene Thermal Minimum was reached (Stötter et al., 1999; Kirkbride and Dugmore, 2001, 2006). But various small glaciers in Tröllaskagi and in Vestfirðir Peninsula, in the northwest of Iceland, had advances slightly greater than those of the LIA (Stötter et al., 1999; Principato, 2008).

There is a controversy whether the dynamics of the IIS expansion and deglaciation affected the whole of Iceland or the marginal mountain zones, especially in the Vestfirðir Peninsula in the northwest, where there is currently an ice-cap, the Drangajökull, and in the north, in the Tröllaskagi Peninsula, affected by autonomous glacial systems. In this context, different types of evidence suggest that ice-free areas and nunataks existed on the summits of the above mentioned peninsulas of Vestfirðir and Tröllaskagi and their immediate surroundings (Sigurvinsson, 1983; Ingólfsson, 1991; Norðdahl, 1991a; Ingólfsson and Norðdahl, 1994; Rundgren and Ingólfsson, 1999; Andrews et al., 2000; Geirsdóttir et al., 2009; Geirsdóttir, 2011).

Recent research carried out in Vestfirðir clarifies the situation for this peninsula, demonstrating the importance of the local ice-cap during the LGM and during the whole deglaciation of this peninsula (Principato et al., 2006; Principato and Johnson, 2009; Brynjólfsson et al., 2014, 2015a; Hole, 2015). The ice-free areas were minimal during the LGM, but the erosion of the highest surfaces was also minimal. In fact, the low erosive capacity of the ice-caps on the flat summits of Vestfirðir has recently been pointed out, as these are cold-based glaciers, compared with the intense erosive capacity of the glacial outlets channelled by the great valleys and fiords (Brynjólfsson et al., 2014, 2015a; Hole, 2015). 
In the case of Tröllaskagi, in spite of the considerable scientific activity which had these mountains as its aim from the 1970s to the 1990s, some important problems still remain unsolved. The aim of this present study is to synthesize the recent advances in the understanding of the landscape and its dynamics in the Tröllaskagi Peninsula and find the origin of its significant difference from the rest of the Iceland.

\section{Tröllaskagi Peninsula settings}

The Tröllaskagi Peninsula is limited by Skagafjödur fiord to the west and the Eyjafjödur fiord to the east (Fig. 1). The Skagafjödur fiord, separating Tröllaskagi from the Skagi Peninsula, has its valley head close to the Hofsjökull glacier, in Central Iceland. The Eyjafjödur fiord separates the Tröllaskagi Peninsula from the Flateyjarskagi Peninsula. This fiord is the continuation of the Eyjafjarðardalur valley, also with its valley head in the highlands, close to Hofsjökull glacier. The Peninsula is formed by stacked horizontal or semi-horizontal Miocene basaltic flows, alternating with layers of sediments and clayey palaeosoils (red interbeds), which become plastic on exposure to hydration and gravity. This basalt plateau is topped by flat summits with altitudes of 1000-1500 m, intensely dissected by the drainage network, which forms flat-bottomed valleys with steep walls. The headwalls of these valleys are cirques, 167 of which host alpine glaciers, mostly north-facing and sheltered from the wet southerly winds. A minority of these glaciers are debris-free glaciers, but most of them are debris-covered and rock glaciers. The few existing debris-free glaciers are very sensitive to climatic changes, especially to summer temperature changes, and as a result have deposited many moraine ridges during their deglaciation (Eythorsson, 1935; Caseldine, 1985). In contrast, the debris-covered and rock glaciers appear highly static in terms of present climatic changes and their termini are not normally preceded by moraines (Martin et al., 1991). The origin of these debris-covered and rock glaciers is under discussion between the authors who consider they were formed during the LIA (Hamilton and Whalley, 1995; Whalley et al., 1995a) and those who maintain that they were formed after deglaciation, but that their activity may have intensified in the cold periods of the second half of the Holocene (Kellerer-Pirklbauer et al., 2007). In any case, these formations derive from previous glaciers covered with debris from intense wall activity (Whalley and Martin, 1994).

The valleys slopes in Tröllaskagi are extremely unstable, affected by numerous rock slope failures and deep-seated gravitational slope deformation, often of significant magnitude, where the red interbed layers act as decollement levels (Jönsson, 1976; Feuillet et al., 2014; Cossart et al., 2014). These macro-mass movements developed as a result of deglaciation during the early Holocene (Mercier et al., 2013; Cossart et al., 2014; Coquin et al., 2015), although in fact some are still active (Wangensteen et al., 2006). In addition, highly active solifluction processes were widespread on the slopes of the Tröllaskagi, especially during the coldest periods at the end of the Pleistocene and the Holocene, as occurred during the Younger Dryas and the LIA (Veit et al., 2011).

The 1940-1970 data series show a mean annual temperature of $2-4^{\circ} \mathrm{C}$ on the Tröllaskagi coasts and -2 to $-4^{\circ} \mathrm{C}$ on the summits. The precipitation is among the lowest 
in Iceland, due to the rain shadow of the great central volcanoes which block the wet SW winds, and oscillates between $400 \mathrm{~mm}$ on the coast and $1200 \mathrm{~mm}$ on the summits (Einarsson, 1976).

\section{The deglaciation of Tröllaskagi Peninsula}

The recent application of Cosmogenic Exposure Dating (CED) on polished bedrock, moraine, erratic and rock glacier boulders has increased our knowledge of the deglaciation of the different landforms of Tröllaskagi Peninsula (Palacios et al., 2015, 2016).

\subsection{The deglaciation of the Tröllaskagi main valleys and fiords}

There is very little previous data available on the deglaciation of the Skagafjödur (Fig. 1). However, to the west of the fiord on the Skagi Peninsula studies have been undertaken of pollen, diatom and carbonate analysis in the sedimentary series of Lake Torfadalsvatn and other nearby lakes, situated in the north extreme of the peninsula at around 20-40 m a.s.l. (Rundgren, 1995, 1999). Deglaciation had already occurred during the Allerød stadial, reaching mean temperatures as high as $10^{\circ} \mathrm{C}$ during the warmest months. During the Younger Dryas severe cooling occurred with a significant impact on the vegetation. After a brief temperature enhancement period there was a further Preboreal cooling. The temperature increased definitively from 10 ka onwards. Many of the large-scale landslides which have been dated in Skagafjödur coincide with this date, indicating that the valleys were recently deglaciated (Mercier et al., 2013; Cossart et al., 2014; Coquin et al., 2015).

The existing information on the deglaciation of Eyjafjödur is summarised by Norðdahl (1991b), demonstrating that up to a total of 12 submarine frontal morainic ridges have been identified, from the mouth of the fiord to its head, although at the present day none can be observed on the surface (Fig. 1). During deglaciation, the tongue which flowed through the fiord blocked the drainage of the right lateral valley of Dalmynni-Fnjóskadalur and specifically in the Fnjóskadalur valley formed up to 8 lacustrine layers. Norðdahl (1991b) relates these ice-dammed lake levels with advances of the glacial tongue which formed 7 frontal moraine arcs to the north of the mouth of the Dalsmynni Valley. When the glacial terminus retreated from the Dalsmynni mouth, the ice-dammed lake was definitively drained. Einarsson (1967, 1973) using palynological data and comparative stratigraphy, deduces that this occurred at approximately $12 \mathrm{ka}$, with the position of the glacier snout at the present head of the fiord at $11 \mathrm{ka}$, dates later confirmed (Norðdahl, 1991b). Skógar tephra is found at the base of the lacustrine sedimentary series of Fnjóskadalur, with a calculated age of $17 \mathrm{ka}$, which would indicate the onset of the glacial obturation of the valley (Norðdahl, 1991b).

Terminal moraines have been found in other tributary valleys of the Eyjafjödur, indicating the existence of glacial advances which interrupted deglaciation, as in Ólafsfjördur and Svarfaðardalur, but these have not been dated. In the Flateyjarskagi 
Peninsula moraines have been found indicating a late recovery of the glaciers dated to around $10 \mathrm{ka}$ BP. This finding has served to attribute this same date to similar moraines in the Eyjafjödur tributary valleys (Norðdahl, 1991b).

The results obtained by the application of CED methods in Skagafjödur and in Eyjafjödur fiords indicate that the deglaciation phases in both were exactly the same (Palacios et al., 2015, 2016) (Fig. 2 and 3). The mouths of the Skagafjödur and Eyjafjödur fiords were definitively abandoned by the glacier terminus just after the Oldest Dryas maximum and the glacier terminus retreated definitively from the middle reach of the fiords during the Bølling/Allerød stadials. The minimum date of deglaciation in the Skagafjödur, from its origin in the LIA moraines of the Hofsjökull glacier to the coast, close to Sauðarkrókur village, was $11.4 \pm 1.0 \mathrm{ka}$. These results suggest a scenario of abrupt, rapid deglaciation of this valley at the Early Preboreal period. The results from Eyjafjarðardalur suggest a similar deglaciation period (Palacios et al., 2015, 2016). According to the results obtained, the deglaciation of the Skagafjödur valley and of Eyjafjödur is completely coherent with earlier publications on IIS deglaciation and the paleoenvironmental evolution of Iceland during the Late Pleistocene.

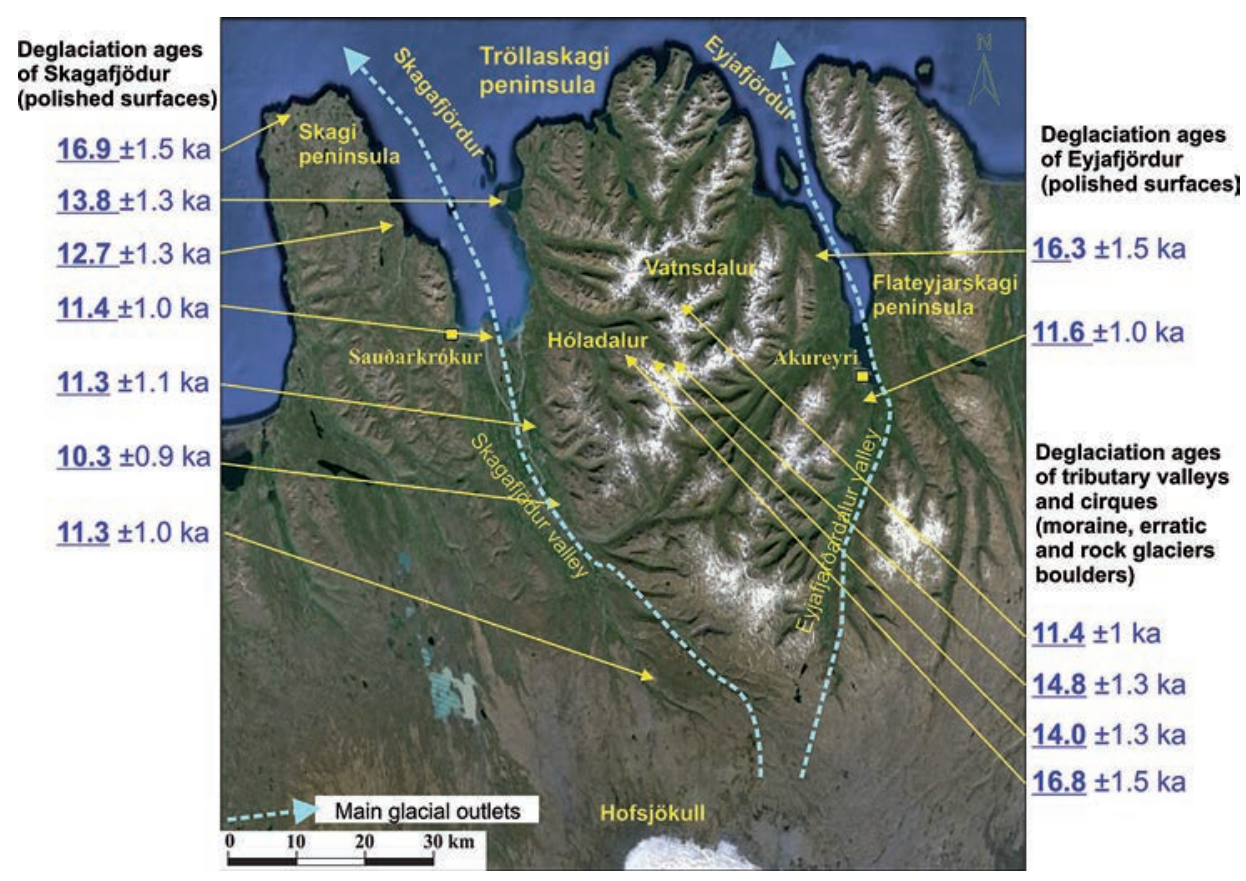

Figure 2. Location of the samples and dates obtained by CED methods, according to Palacios et al. (2015, 2016), in the main IIS outlets: Skagafjödur and Eyjafjödur fiords, and in the tributary valleys: Vantsdalur and Hóladalur, just inside the Tröllaskagi Peninsula (Google Earth image, 2013). 

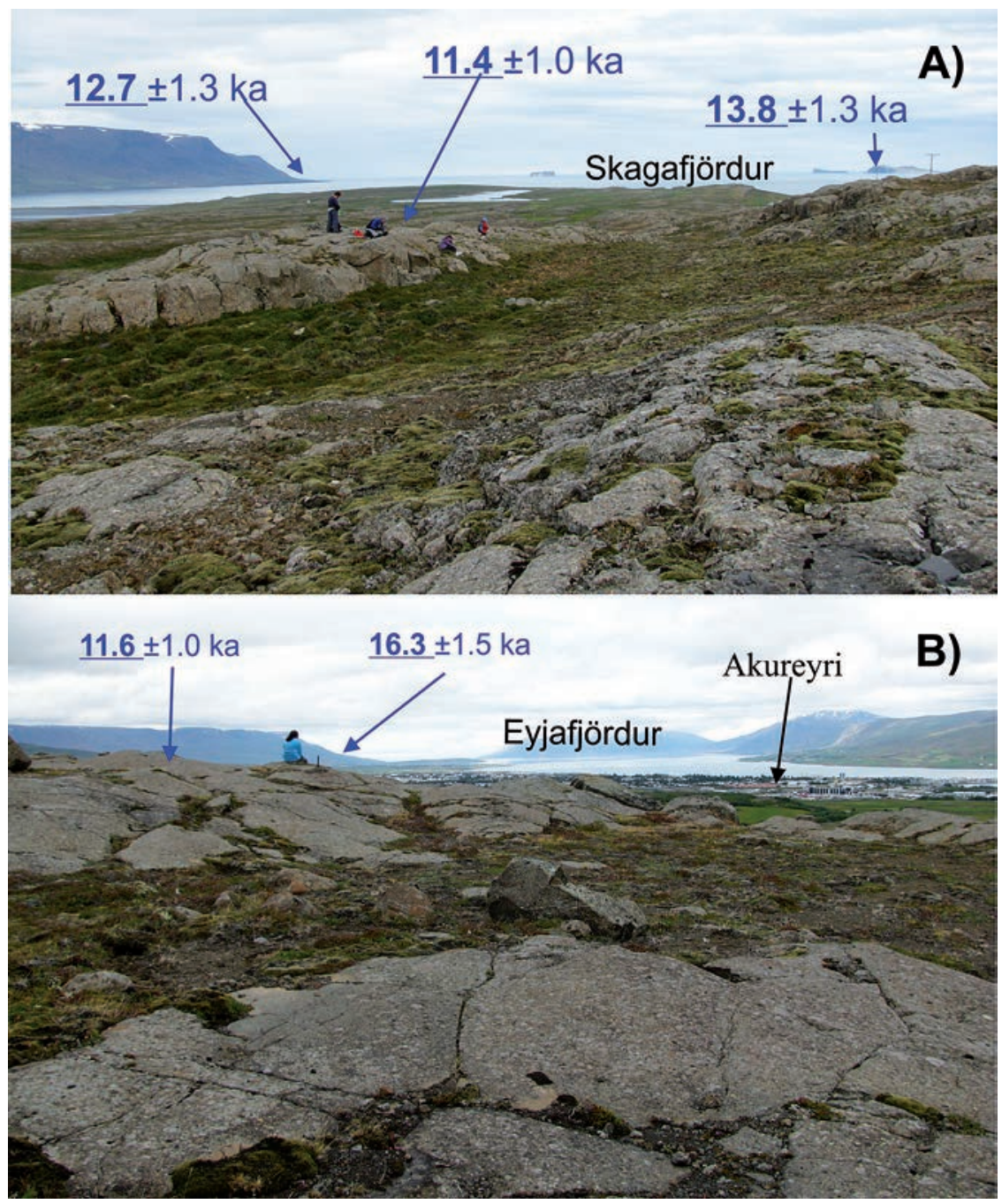

Figure 3. Photos of A) Polished surfaces at the head of Skagafjödur fiord, close to Sauðarkrókur village, reached by the snout of the glacial outlet during the Younger Dryas and Early Boreal periods. B) Polished surfaces at the head of Eyjafjödur fiord, close to Akureyri village, reached by the snout of the glacial outlet during the Younger Dryas and Early Boreal periods. In both photos, dates of older polished surfaces, to the mouth of the fiords, are indicated. The dates were calculated in Palacios et al. $(2015,2016)$. Photos: Nuria Andrés.

\subsection{The deglaciation of Tröllaskagi internal valleys and cirques}

Apart from the frontal moraines mentioned above in a few tributary valleys in the Eyjafjödur area, no others have been shown to have existed in all the Tröllaskagi 
mountains earlier than those of the LIA. The only exceptions are three cirques where moraines found a few metres in front of those from the LIA have been dated, all with ages more modern than 5.4 ka (Stötter et al., 1999). Pollen studies in different valleys of the Tröllaskagi confirm the start from $4.2 \mathrm{ka}$ of a series of cold periods which facilitated the neoglacial advances. (Caseldine and Hatton, 1994; Wastl et al., 2001). Stötter et al. (1999) reported six pre-LIA advances in: $5.4 \mathrm{ka}, 4.7 \mathrm{ka}, 3.5-3.4 \mathrm{ka}, 1.9 \mathrm{ka}$, $1.4 \mathrm{ka}$, and $0.9 \mathrm{ka}$ ca BP, which have been observed in three cirques: Vatnsdalur (Stötter, 1991), Bægisárdalur (Häberle, 1994) and Barkárdalur (Häberle, 1991) (Fig. 1). In many cases, these moraines were deposited on ground covered by Saksunarvatn tephra from 10.2 ka (Stötter et al., 1999). Stötter (1991) suggests the possibility that the pre-LIA moraines in the Vatnsdalur cirque are due to surges. This possibility was confirmed by Brynjólfsson et al. (2012), who studied various surges occurring in the $20^{\text {th }}$ century in valleys adjacent to Vatnsdalur, which left very similar moraines. In fact, these authors consider that this must be a usual process in the small Tröllaskagi glaciers. Surges, with no direct relationship to the climatic crises, were also very important in Vestfirðir (Brynjólfsson et al., 2014, 2015b). In any case, lichenometric studies of many glacial deposits in the Tröllaskagi cirques demonstrate that in the great majority of the cirques the main advance after Saksunarvatn tephra (10.2 ka) was during the LIA (Caseldine, 1987; Kugelmann, 1991; Häberle, 1991, 1994).

The main tributary valleys of Tröllaskagi (Hjaltadalur, Hóladalur, Kolbeinsdalur, Deildalur, Unadalur, tributaries of Skagafjödur and Hogárdalur, Skidaðalur and Svafarðadalur, tributaries of Eyjafjödur) (Fig. 1) were explored for four summers without finding any glacial landforms (moraine and erratic boulders or polished surfaces) which allowed CED methods to be applied (Palacios et al., 2015, 2016). The large number of landslides, and also intense solifluction, has transformed and covered the glacial landforms of these valleys. On the other hand, the slopes and floors of the valleys are completely covered with tephra and aeolian deposits. In fact there are no bedrock outcrops, or any existing outstanding blocks in the relief, with the exception of those generated by postglacial rock avalanches. The difference in age between these mass movements is evident in the landscape. Over time they were covered by solifluction lobes and tephra until gradually the boulder outcrops disappeared and no boulders protrude in the oldest.

The glacial landforms which allow application of CED methods inland in Tröllaskagi are only found in the cirques situated at the bottom of the tributary valleys, very near the present glacier termini and a few metres from what have been considered LIA landforms (Fig. 2). The Vatnsdalur cirque (Fig. 1 and 4), a tributary of Svafarðadalur, was chosen as an example of the debris-free glacial cirques where moraines had already been dated with radiocarbon and tephrachronology (Stötter, 1991, ages recalibrated in Wastl and Stötter, 2005). The cirques of the Hóladalur headwall were also selected (Fig. 1 and 5), where various generations of rock glaciers and a debris-covered glacier had already been recognised (Kellerer-Pirklbauer et al., 2007). 


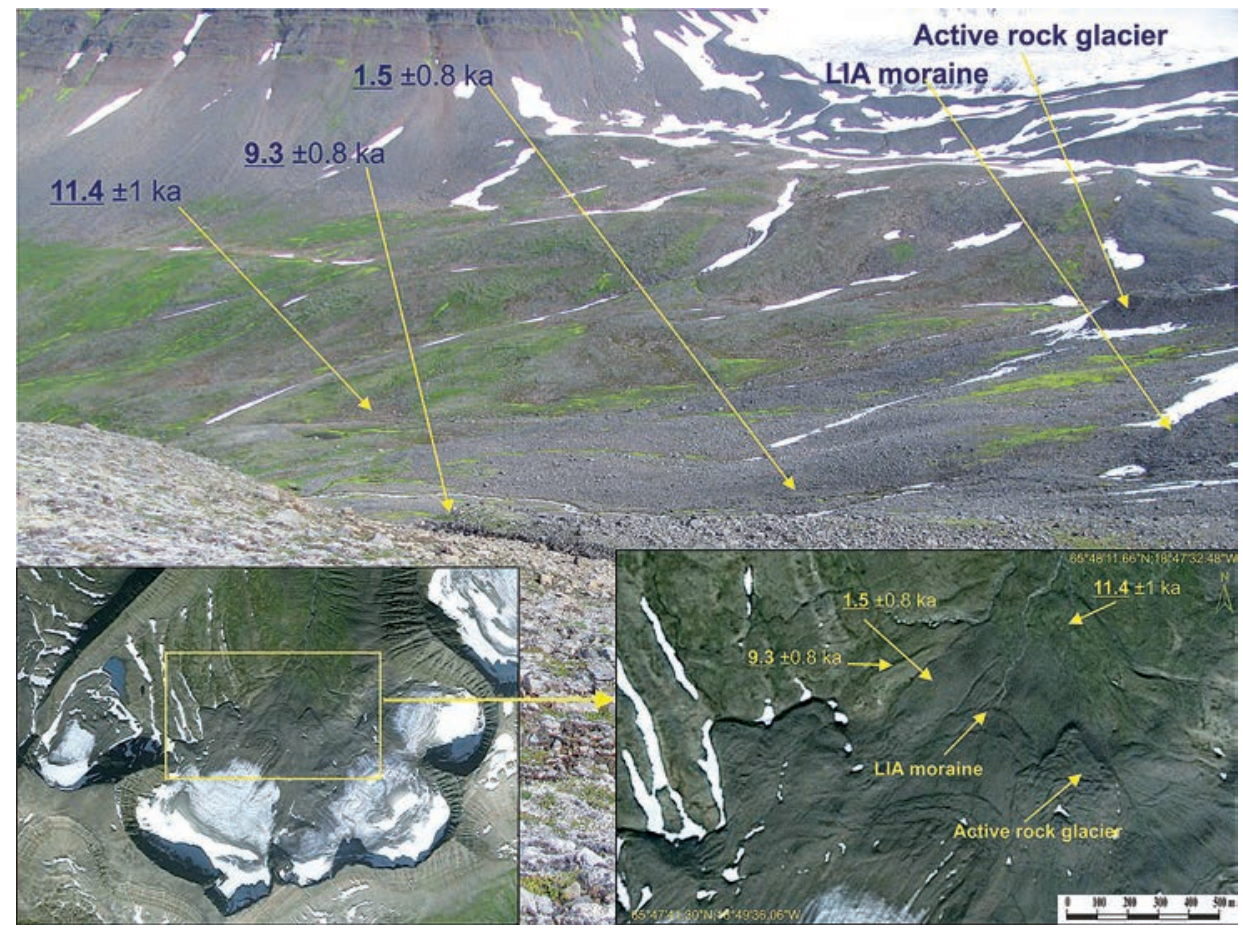

Figure 4. Cirque of Vatnsdalur, where the limits of LIA moraines and active rock glacier is indicated. The dates correspond to erratic boulders and were calculated in Palacios et al. (2015, 2016). Photos: Nuria Andrés and Google Earth Images (2013).

The results obtained in Vatnsdalur seem to confirm the considerable dynamism of these glaciers, especially in the second half of the Holocene, whether they were very sensitive to climatic changes or because of their facility for forming surges, or for both of these reasons at the same time. On the other hand, the minimum dates obtained from the boulders furthest away from the glacier termini indicate that during the Younger Dryas, when the glacier termini of the fiords were found $100 \mathrm{~km}$ from the LIA moraines of the Hofsjökull, in the interior of Tröllaskagi they had only moved $700 \mathrm{~m}$ with respect to the LIA maximum (Fig. 2 and 4) (Palacios et al., 2015, 2016).

The results obtained in the cirques in the Hóladalur valley are even more surprising than in Vatnsdalur (Palacios et al., 2015, 2016). In front of the debris-covered glaciers, considered to have been formed during the LIA, there is only one diffuse moraine or erratic boulder alignment where the minimum ages indicate a possible origin in the deglaciation during the Bølling/Allerød stadials (Fig. 2 and 5). And on the other hand, the origins of the fossil rock glaciers underneath the active rock glaciers also have a definitive stabilization date during the Bølling/Allerød stadials or even earlier. In this case, while the glaciers occupied the mouths of the great fiords which surround Tröllaskagi, almost $170 \mathrm{~km}$ from the present glaciers in central Iceland, in Hóladalur the length of the glaciers did not exceed $2 \mathrm{~km}$. 

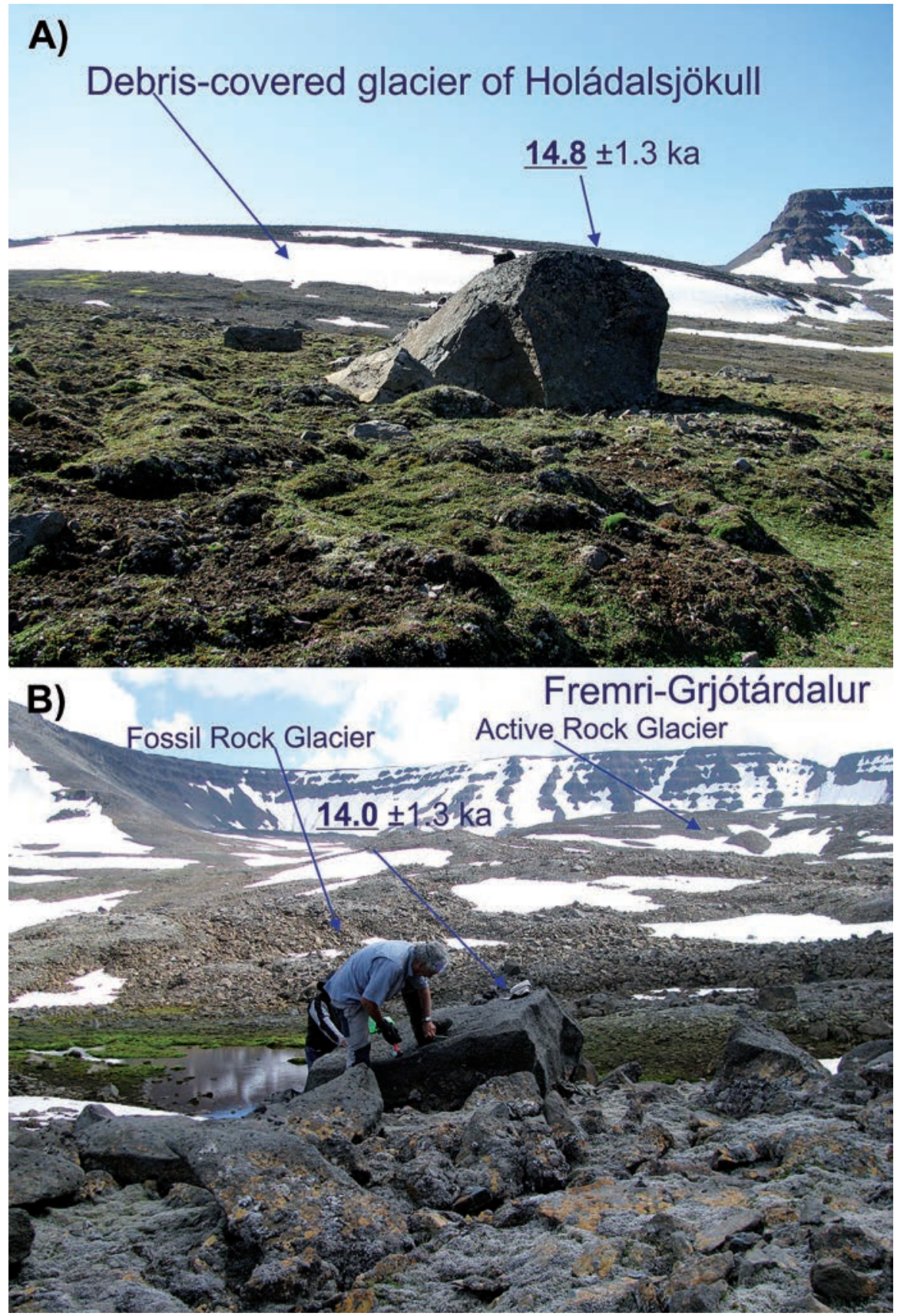

Figure 5. Cirques of Hóladalur. A) Debris-covered glacier of Hóladalsjökull and a erratic boulder dated, located $600 \mathrm{~m}$ of the glacial snout. B) Rock Glaciers, active and fossil, of Fremri-Grjótárdalur. One boulder of the fossil rock glacier was dated. The dates were calculated in Palacios et al. $(2015,2016)$. Photos: Nuria Andrés. 


\subsection{Glacial evolution of Tröllaskagi flat summits}

Ingólfsson (1991) and Norðdahl (1991b) summarised the studies carried out on the possible glaciation of the Tröllaskagi summits, and show how most geomorphologists and palaeobotanists in the early 20th century defended an ice-free scenario for these summits during the LGM. Einarsson $(1963,1967,1973)$, collecting all the previous information on pollen analyses, Steindórsson (1963), on vegetation biodiversity, and Sigbjarnasson (1983) on geomorphological evidences, maintained that almost all the Tröllaskagi summits were deglaciated in the LGM. On the other hand, the geomorphologist Einarsson (1966), analysed evidence of glacier thickness in Eyjafjödur and modeled its extent during the LGM, reaching the conclusion that part of the summits of Tröllaskagi and Flateyjarskagi were not covered by glaciers in the LGM. Norðdahl (1991a, 1991b) emphasises that most of the great Tröllaskagi valleys run $\mathrm{N}-\mathrm{S}$, thus facilitating the flow of the IIS outlets. But important sectors of these mountains, affected by a dendritic drainage network, were outside these flows. This hypothesis was confirmed by recent simulation models (Hubbard et al., 2006) where, as stated by Einarsson y Norðdahl, the thickness of the IIS allowed extensive ice-free platforms to exist in Tröllaskagi during the LGM, which served as a refugium for the flora and fauna (Rundgren and Ingólfsson, 1999).

CED dating methods could not be applied in various flat summit areas between the tributary valleys mentioned above (Fig. 1) as no glacial landforms (erratic boulders or polished surfaces) were discovered (Palacios et al., 2015, 2016). These surfaces are completely covered by blockfields, often forming pattern grounds, without any existing bedrock outcrops. Only a few erratic boulders have been identified from aerial photography of some of the summits, and attempts will be made to sample these in the near future. In this regard, the morphology of the flat summits in Tröllaskagi is completely different from the summits of other areas of Iceland, such as the Vestfirðir Peninsula or the central highlands where, although blockfields do also exist, the landscape is predominantly glacial, with polished surfaces, basin lakes, erratic boulders, etc.

\subsection{Evidences from Tröllaskagi deglaciation}

The Skagafjödur fiord and valley, the western boundaries of the peninsula, and the Eyjafjödur fiord and Eyjafjarðardalur valley, the eastern limits, display very similar behaviour and fully agree with what is described for the IIS. The glaciers, after the LGM, reached the mouth of the fiords during the Oldest Dryas. The glaciers then retreated slowly, occupying the middle reach of the fiords by the end of the Oldest Dryas. During the Bølling/Allerød stadials the glaciers retreated, this time almost disappearing, to reform again in the Younger Dryas with the termini reaching again the head of the fiords. After a new retreat, the glaciers advanced again, re-reaching the head of the fiords during the Early Preboreal. From 11.4 ka the glaciers retreated abruptly from these positions, until they were reduced to their current limits over just a few centuries. In inland Tröllaskagi, on the contrary, there is no evidence of recent glaciation on the summits or in the middle reaches of its tributary valleys. It is not known whether they were affected by the LGM, but they were not affected by the Oldest Dryas or by the Younger Dryas. On the 
contrary, during these periods of generalized advances of the Icelandic central glaciers, in Tröllaskagi small glaciers formed only in the cirques, on average approximately $1 / 3$ larger than those existing at the present time. In the cirques where there was no important activity on the walls, the glaciers remained debris-free, and their termini oscillated as new cold periods originated in the second half of the Holocene, above all during the LIA. Where the geomorphological activity of the cirque walls was intense, the glaciers derived in rock glaciers and debris-covered glaciers.

Thus, a first fundamental factor to understand the characteristics of the alpine landscape in the Tröllaskagi Peninsula is the fact that it was not affected inland by a great ice-sheet during the Late Pleistocene and Holocene. The period occurring between the deglaciation of the valleys and most of the cirques in Tröllaskagi is much longer than in the rest of Iceland, and therefore the landscape has been transformed more intesely by aeolian, periglacial and gravitational processes.

\section{The dynamic of debris-free glaciers in Tröllaskagi Peninsula}

To understand the dynamics of the debris-free glaciers in the Tröllaskagi cirques, the Gljúfurárjökull glacier was selected at the Skiðadalur valley head, a tributary of the Eyjafjördur fiord, and the Western and Eastern Tungnahryggsjökull glaciers, at the Kolbeinsdalur valley head, a tributary of the Skagafjördur (Fig. 1, 6 and 7).

The Gljúfurárjökull and Tungnahrýggsjökull glaciers reached their maximum known extension in the LIA during the second half of the $19^{\text {th }}$ century, coinciding with the maximum advance of the ice-caps in central Iceland. However, the maximum extension was not completely synchronic in the two glaciers: in the Gljúfurárjökull it occurred in the last decade of the 19th century, around 1898-1903, while in the Western Tungnahrýggsjökull it was earlier, in 1868 (Caseldine and Cullingford, 1981; Caseldine, 1983, 1985). The results obtained by Caseldine y Stötter (1993) show that during the LIA maximum the Tröllaskagi climate was characterized by a summer temperature $0.3{ }^{\circ} \mathrm{C}$ lower than the $1961-1990$ series and a winter precipitation of $1450 \mathrm{~mm}$ at the Equilibrium Line Altitude (ELA), located at $946 \mathrm{~m}$ a.s.l.

The rise in temperatures from the end of the $19^{\text {th }}$ century caused the retreat of the glaciers from their positions during the LIA. The only and latest data published for the Western Tungnahrýggsjökull glacier (Caseldine, 1985) show that the retreat began decades earlier than in Gljúfurárdalur, due in part to the steeper gradient in this valley and the lower thickness of the ice. Its retreat over the $19^{\text {th }}$ century was interrupted by different advance or stable phases, during which new moraines were formed: 1876-1878, 1882-1887 and 1898-1903.

In the case of the Gljúfurárjökull, the temperature rise during the first two decades of the $20^{\text {th }}$ century resulted in an important retreat of $250 \mathrm{~m}$ from the LIA limits and a rise of the ELA to 1060-1100 m (Caseldine, 1983, 1987). In this case, the retreat was also interrupted with the formation of moraines in 1910 and 1913-1917. Subsequently, between the mid-1920s and 1930 the recession of the glacier slowed. The retreat accelerated again in the early 1930s (200 m), again interrupted by minor advances which 
enabled the formation of moraines around 1935. In the late 1940s there was another short readvance which ended around 1950-1951 (Caseldine, 1983) leaving a continuous sequence of moraines. After that, Gljúfurárjökull continued to retreat, reaching a minimum in the mid-1960s. The data for the glacier retreat since the LIA obtained by Caseldine y Cullingford (1981) using photogrammetry and lichenometry show a retreat of the glacier terminus of $265 \mathrm{~m}$ between 1939 and 1972, and $151 \mathrm{~m}$ between 1953 and 1960. After recording the minimum extension, the glacier trend changed in 1977. The glacier started a new readvance of greater scope and continuity than those occurring during deglaciation, in response to the lower summer temperatures in the early 1960s. Thus, the terminus advanced $50 \mathrm{~m}$ in 1977-1979, $30 \mathrm{~m}$ in 1979-1981 and $25 \mathrm{~m}$ in 19811983 (Caseldine y Cullingford, 1981; Caseldine, 1983, 1985).

Thus, the situation of the Gljúfurárjökull in 1985 was characterized by the location of its terminus at altitude $580 \mathrm{~m}$ and by an ELA around $960 \mathrm{~m}$ (Caseldine, 1985). The ELA of the series of 48 glaciers in Tröllaskagi was significantly higher, at $992 \mathrm{~m}$ (Caseldine

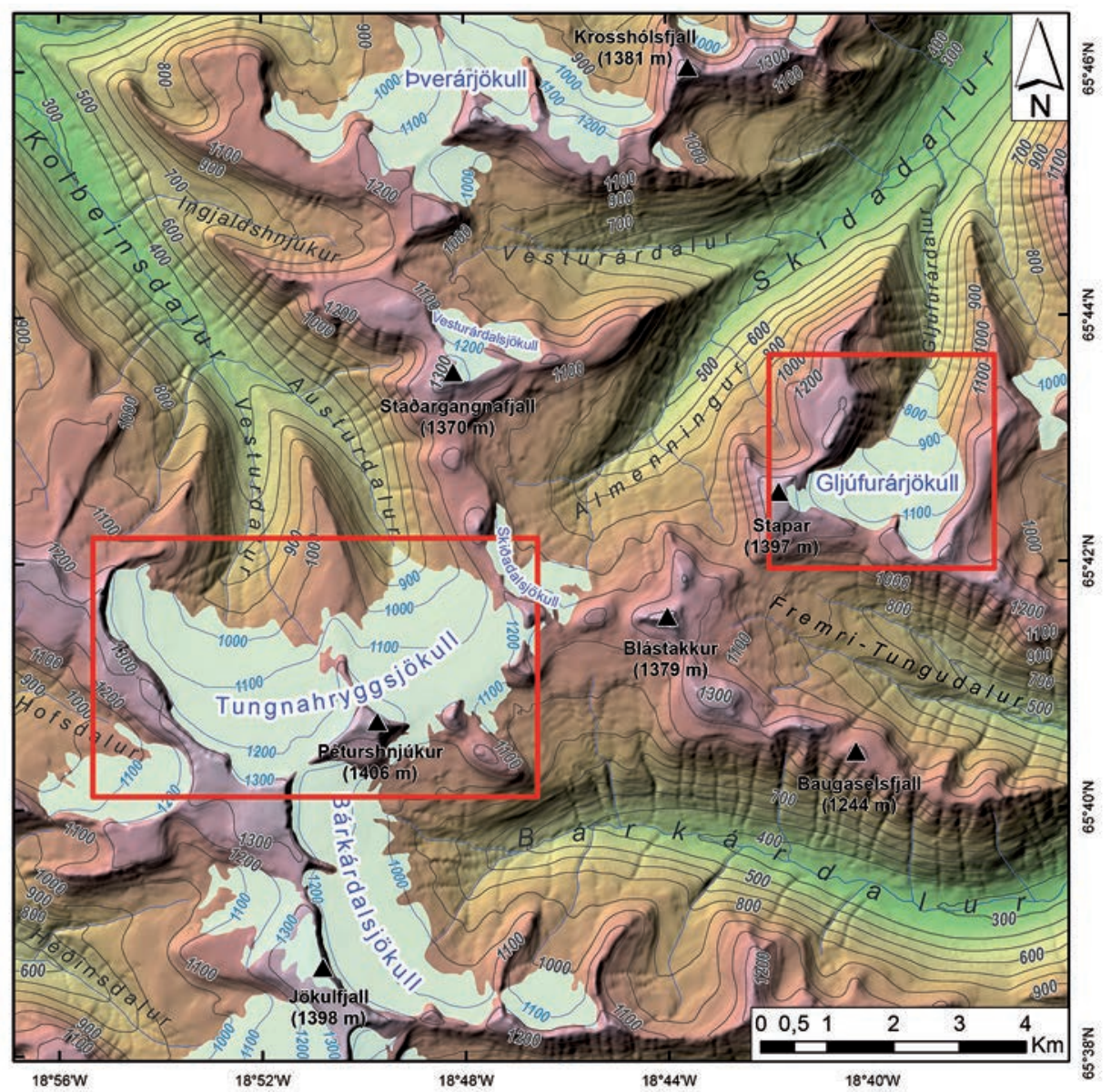

Figure 6. Location of the studied debris-free glaciers: Gljúfurárjökull and Western and Eastern Tungnahryggsjökull glaciers 

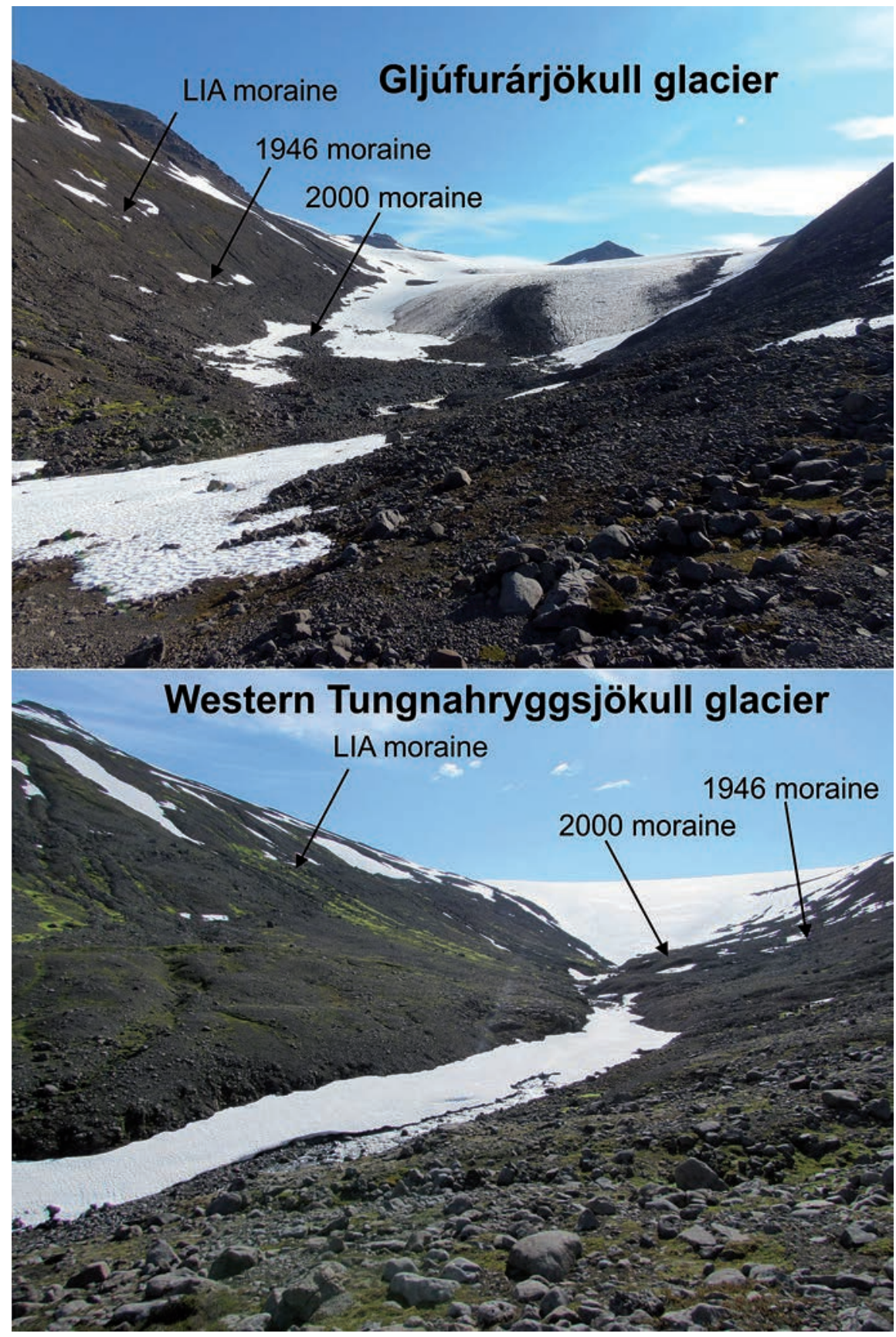

Figure 7. The debris-free glaciers of Gljúfurárjökull and Western Tungnahryggsjökull, with snouts fluctuating from small climatic variations. Photos: Nuria Andrés 
and Stötter, 1993). The research and related publications into the Gljúfurárjökull glacier ended in the late 1980s, just when the trend of the Tröllaskagi glaciers was uncertain. This did not however occur in the study of the temperature evolution, which is described in great detail until the 1990s: Einarsson (1991) distinguished six thermal phases between 1901 and 1990 depending on whether these were cold (1901-1925, 1947-1952 and 19651971) or warm (1926-1946, 1953-1964 and 1972-1990).

There has been no further information since the early 1990s on the evolution of these glaciers. Recent studies have attempted to analyse their recent evolution, using surface and volume evolution, ELA calculations using the Accumulation Area Ratio (AAR) and Area Altitude Balance Ratio (AABR) methods, and their relationship with climate evolution, from the maximum known extension (LIA) until 2013 (Fernández et al., 2015, 2016). This research takes into consideration the data from the following

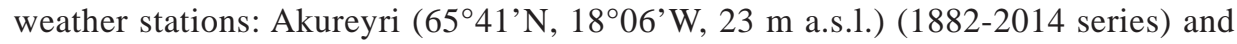

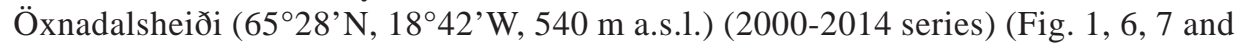
8 and Tables 1,2 and 3$)$.

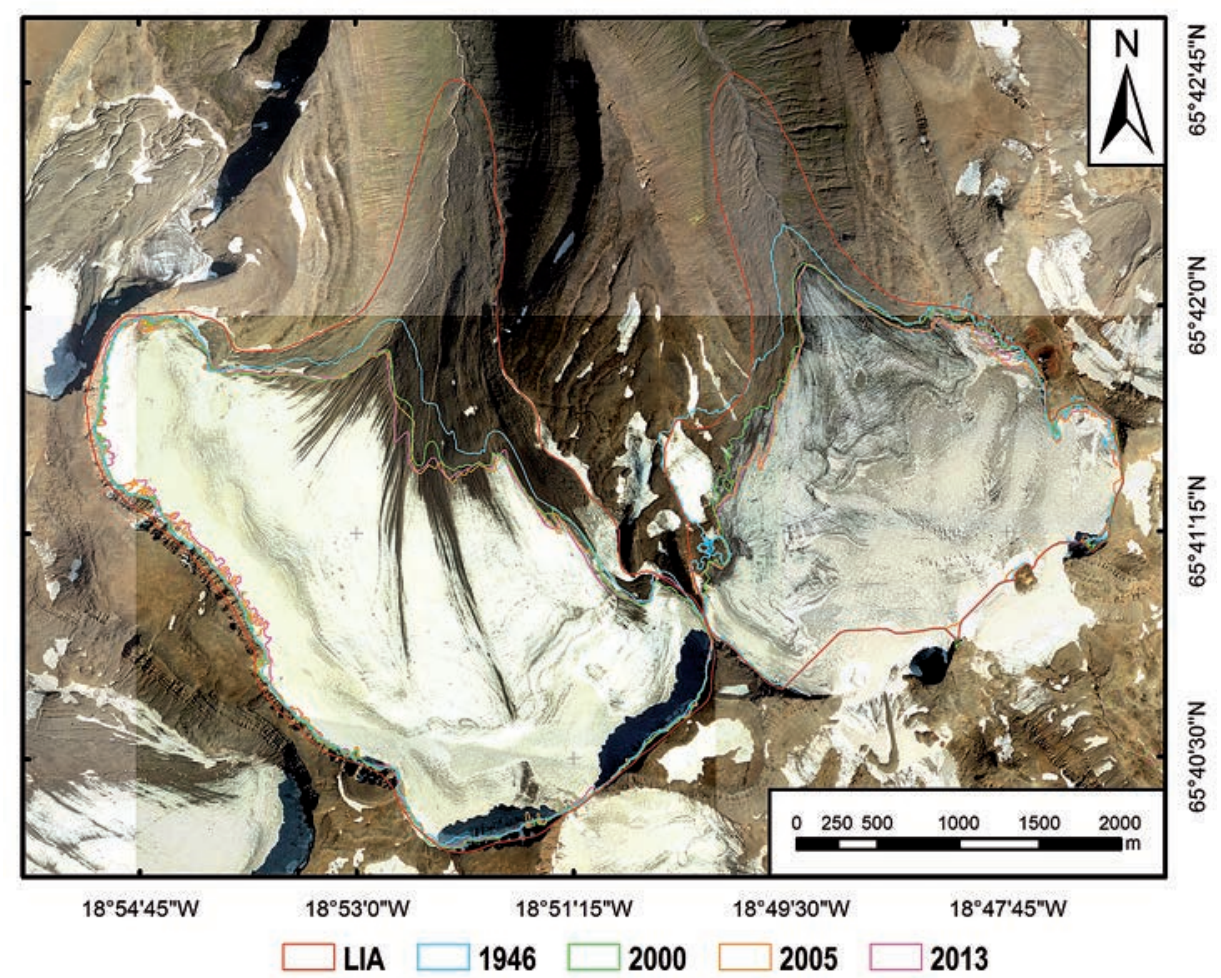

Figure 8. Evolution of the Tungnahryggsjökull Western and Eastern glaciers, from the LIA to 2013, according to Fernández et al. $(2015,2016)$. 
Table 1. Glacial area and volume of debris-free glaciers in Little Ice Age maximum, 1946, 2000, 2005 , and 2013.

\begin{tabular}{|lccccc|}
\hline \multicolumn{7}{c}{ AREA $\left(\mathbf{k m}^{2}\right)$} \\
\hline \multicolumn{1}{|c}{ GIA } & $\mathbf{1 9 4 6}$ & $\mathbf{2 0 0 0}$ & $\mathbf{2 0 0 5}$ & $\mathbf{2 0 1 3}$ \\
\hline Gljúfurárjökull & 4.03 & 3.40 & 3.39 & 3.28 & 3.24 \\
Western Tungnahrýggsjökull & 8.65 & 6.69 & 6.36 & 6.25 & 6.19 \\
Eastern Tungnahrýggsjökull & 5.27 & 4.50 & 4.03 & 3.82 & 3.82 \\
Total area & $\mathbf{1 7 . 9 5}$ & $\mathbf{1 4 . 5 9}$ & $\mathbf{1 3 . 7 8}$ & $\mathbf{1 3 . 3 4}$ & $\mathbf{1 3 . 2 4}$ \\
\hline \multicolumn{1}{|c}{ GOLUME $\left(\mathbf{k m}^{\mathbf{3}}\right)$} \\
\hline \multicolumn{1}{c}{ Glaciers } & LIA & $\mathbf{1 9 4 6}$ & $\mathbf{2 0 0 0}$ & $\mathbf{2 0 0 5}$ & $\mathbf{2 0 1 3}$ \\
\hline Gljúfurárjökull & 6.80 & 5.39 & 5.35 & 5.11 & 5.03 \\
Western Tungnahrýggsjökull & 19.42 & 13.64 & 12.73 & 12.41 & 12.25 \\
Eastern Tungnahrýggsjökull & 9.84 & 7.91 & 6.80 & 6.31 & 6.30 \\
Total volume & $\mathbf{3 6 . 0 6}$ & $\mathbf{2 6 . 9 4}$ & $\mathbf{2 4 . 8 8}$ & $\mathbf{2 3 . 8 4}$ & $\mathbf{2 3 . 5 8}$ \\
\hline
\end{tabular}

Table 2. AAR/AABR-ELAs of debris-free glaciers in Little Ice Age maximum, 1946, 2000, 2005, and 2013.

\begin{tabular}{|c|c|c|c|c|c|}
\hline \multicolumn{6}{|c|}{$A A R-E L A s(A A R=0.67)$} \\
\hline Glacier & LIA & 1946 & 2000 & 2005 & 2013 \\
\hline Gljúfurárjökull & 950 & 977 & 992 & 1001 & 997 \\
\hline Western Tungnahrýggsjökull & 1059 & 1099 & 1107 & 1094 & 1096 \\
\hline Eastern Tungnahrýggsjökull & 1038 & 1074 & 1084 & 1090 & 1081 \\
\hline mean & 1016 & 1050 & 1061 & 1062 & 1058 \\
\hline \multicolumn{6}{|c|}{ AABR-ELAs $(B R=1.5 \pm 0.4)$} \\
\hline Glacier & LIA & 1946 & 2000 & 2005 & 2013 \\
\hline Gljúfurárjökull & 940 & 967 & 982 & 991 & 1007 \\
\hline Western Tungnahrýggsjökull & 1049 & 1089 & 1097 & 1104 & 1106 \\
\hline Eastern Tungnahrýggsjökull & 1028 & 1064 & 1074 & 1080 & 1081 \\
\hline mean & 1006 & 1040 & 1051 & 1058 & 1065 \\
\hline
\end{tabular}

Table 3. Cool and warm periods at Akureyri and Öxnadalsheiði Stations according with MAAT.

\begin{tabular}{|cccc|}
\hline Period & Type & $\begin{array}{c}\text { MAAT at Akureyri } \\
\left({ }^{\mathbf{0}} \mathbf{C}\right)\end{array}$ & $\begin{array}{c}\text { MAAT at } \\
\text { Oxnadalsheiði }\left({ }^{\mathbf{}} \mathbf{C}\right)\end{array}$ \\
\hline $1882-1924$ & Cool & 2.52 & -0.73 \\
$1925-1948$ & Warm & 4.01 & 0.62 \\
$1949-1955$ & Cool & 3.52 & 0.18 \\
$1956-1965$ & Warm & 3.79 & 0.43 \\
$1966-1973$ & Cool & 2.81 & -0.46 \\
$1974-1978$ & Warm & 3.74 & 0.38 \\
$1979-1986$ & Cool & 2.93 & -0.35 \\
$1987-2014$ & Warm & 4.06 & 0.67 \\
\hline
\end{tabular}


During the LIA, the area of the three glaciers as a whole was close to $18 \mathrm{~km}^{2}$, with the Western Tungnahrýggsjökull, with over $8 \mathrm{~km}^{2}$, the most extensive of the three. During the period between the LIA maximum and 2013, the glacier area was reduced by $26.3 \%$. The greater part of the surface loss, $18.7 \%$ equivalent to $14.6 \mathrm{~km}^{2}$, occurred before 1946 . The reduction in the surface area between 1946 and 2013 represents only $7.3 \%$ of the total reduction between the LIA and 2013 when the surface area of the glacier was slightly over $13 \mathrm{~km}^{2}$. On an individual level, the glaciers which evidenced greatest sensitivity were those of the Tungnaghrýggsjökull, with losses exceeding 27-28\%. Likewise, during the LIA maximum the total volume of ice was in excess of $36 \mathrm{~km}^{3}$ with approximately 19.4 $\mathrm{km}^{3}(54 \%)$ concentrated in the Western Tungnahrýggsjökull glacier. The greatest volume loss was also here between the LIA maximum and 1946, with $9 \mathrm{~km}^{3}(25.3 \%)$, while from 1946 to 2013 the loss was $3.3 \mathrm{~km}^{3}(12.5 \%)$. The individual volume losses were again greater for the Tungnahrýggsjökull glaciers (36-37\%) compared to Gjúfurárjökull (26\%). The results of the ELA calculations using the methods mentioned above show a rise at the dates available from the LIA to the present, and also consistently higher values for the Tungnahrýggsjökull glaciers compared with the Gljúfurárjökull (Fernández et al., 2015, 2016). The AAR method obtains a total increase of $42 \mathrm{~m}$ in the overall ELA for the three glaciers, rising from $1016 \mathrm{~m}$ to $1058 \mathrm{~m}$, with the greatest variation concentrated in the period between the LIA and 1946 (+34 m). The difference between 1946 and 2000 is only $+11 \mathrm{~m}$, while from 2000 onwards the ELA remains practically stable at $\approx 1060 \mathrm{~m}$. The AABR method obtains a higher ELA for all dates, with lower values $(\approx 10 \mathrm{~m})$ than those obtained with the AAR method, but obtains a rise of $14 \mathrm{~m}$ from 2000 to 2013. Whichever the method used, the behaviour of the Western Tungnahrýggsjökull glacier is different from the other two, with more marked increases and decreases (Fernández et al., 2015, 2016).

In general terms, the evolution of the Mean Annual Air Temperature (MAAT) at Akureyri shows an increase from the LIA to the mid-1940s, followed by a decrease until the early 1980s, and a further increase, still ongoing at present, accentuated just after the year 2000. 4 cold periods have been identified during the period 1882-2014 (1882-1924; $1949-1955$; 1966-1973; 1979-1986) and 4 warm periods (1925-1948; 1956-1965; 19741978 ; 1987-2014), which overall represent 66 and 67 years respectively. The cold period $1882-1924\left(2.5^{\circ} \mathrm{C}\right)$ describes the climatological conditions of the LIA, and contrasts with the periods $1925-1948\left(4.01^{\circ} \mathrm{C}\right)$ and $1987-2014\left(4.06^{\circ} \mathrm{C}\right)$, the warmest in the series (Fernández et al., 2015, 2016).

In summary, it can be observed that the response of the debris-free glaciers in Tröllaskagi is highly sensitive to the alternating cold and warm periods, within the overall deglaciation trend since the LIA maximum.

\section{The dynamic of debris-covered glaciers and rock glaciers in Tröllaskagi Peninsula}

It has already been shown that debris-covered and rock glaciers have traditionally been considered much less dynamic than debris-free glaciers (Martin et al., 1991). Two main cirques in the Hóladalur valley, both oriented north, were studied to determine their dynamics. The western cirque, Fremri-Grjótárdalur, hosts a series of active rock glaciers, and the eastern one a debris-covered glacier, known as Hóladalsjökull (Fig. 1, 5 and 9). 

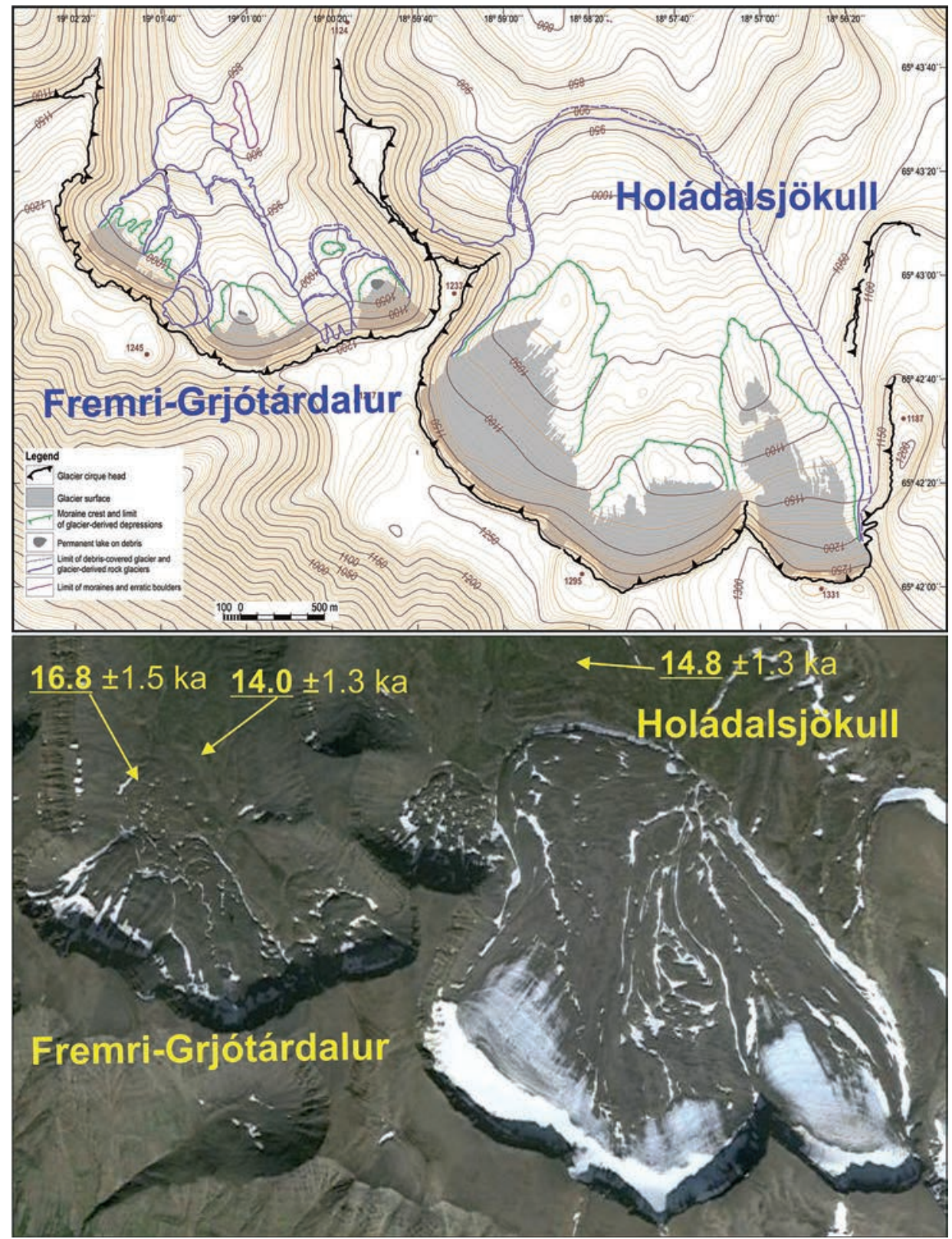

Figure 9. Fremri-Grjótárdalur rock glaciers and Hóladalsjökull debris-covered glacier: geomorphological sketch and ortophoto (Google Earth). Ages of the erratic and fossil rock glacier boulders are indicated, according to Palacios et al. $(2015,2016)$. 
Lilleøren et al. (2013) identified 265 landforms related to the presence of permafrost in Tröllaskagi, of which 178 are rock glaciers and 87 debris-covered glaciers. The Nautárdalur is the only rock glacier which has been monitored in Tröllaskagi (Martin and Whalley, 1987; Martin et al., 1991; Whalley and Martin, 1994; Hamilton and Whalley, 1995). The results of these studies show that the rock glaciers started to develop when small cirque glaciers were covered with debris from the unstable cirque walls, forming an insulating cover on the glacier ice, enabling its preservation to the present day (Whalley and Martin, 1994, Hamilton and Whalley, 1995). This occurred during or immediately after the LIA in response to a climate change which affected the mass balance of the small cirque glaciers and debris production rates on the cirque walls. This has been demonstrated by lichenometric dating in the Nautárdalur rock glacier, with boulders covered by 200-year-old lichens (Martin et al., 1994; Hamilton and Whalley, 1995).

A numerical model of the regional distribution of permafrost in Iceland has recently been developed by means of a gridded MAAT for the 1961-1990 period interpolated from point meteorological data (Etzelmuller et al., 2007). This permafrost model shows the extensive and almost continuous presence of permafrost in the Trolläskagi Peninsula, with a limit at around 800-900 m. Lilleøren et al. (2013) confirm the existence of permafrost currently above $800 \mathrm{~m}$ a.s.l. at certain inland locations in Tröllaskagi.

After these studies on the existence of permafrost, other new studies have also appeared on rock glaciers and debris-covered glaciers, precisely in the Hóladalur valley, in Fremri-Grjótárdalur rock glaciers and in Hóladalsjökull debris-covered glacier. Farbrot et al. (2007) studied the ground surface temperature in the Fremri-Grjótárdalur rock glacier and in its highest area, with mean temperatures (2005-2006) between -0.5/$0.2^{\circ} \mathrm{C}$ and $-2.3^{\circ} \mathrm{C}$ respectively. Wangensteen et al. (2006) and Kellerer-Pirklbauer et al. (2007) calculate approximate estimated surface velocities by streamline interpolations to calculate the age of these glaciers. Kellerer-Pirklbauer et al. (2007) apply relative surface dating using a Schmidt-hammer. Farbrot et al. (2007) study the headwall recession rates of these cirques. These studies point to a much older age for the formation and development of these rock glaciers than that proposed for the Nautárdalur rock glacier. Wangensteen et al. (2006) calculate an age of 4500-5000 years for the Fremri-Grjótárdalur rock glaciers, although they highlight the formation of more recent lobes of around 1000-1500 years. Kellerer-Pirklbauer et al. (2007) consider that their formation may have derived from as early as the deglaciation in the late Younger Dryas, Preboreal or $8.4 \mathrm{ka}$ event. The lower lobes would have remained inactive during the Holocene Thermal Maximum and the upper lobes would have started their activity with the onset of the Holocene cold periods around $3 \mathrm{ka}$.

Studies of the rock glacier dynamics also focused earlier on the Nautárdalur valley and more recently on Hóladalur. The studies using a theodolite carried out by Martin and Whalley (1987) and Whalley et al. (1995a, 1995b) in Nautárdalur obtain velocities of $0.2 \mathrm{~m} \mathrm{yr}^{-1}$ to $0.25 \mathrm{~m} \mathrm{yr}^{-1}$, for a 17 year period (1977-1994). Wangensteen et al. (2006) analysed the dynamics of the Fremri-Grjótárdalur rock glaciers and the Hóladalsjökull 
debris-covered glacier, using digital photogrammetry and cross-correlation matching of multi-temporal orthophotos from 1985 and 1994. Over a 9 year period these authors obtain velocities ranging from $0.07 \mathrm{~m} \mathrm{yr}^{-1}$ to $0.84 \mathrm{~m} \mathrm{yr}^{-1}$ in Fremri-Grjótárdalur and from $0.07 \mathrm{~m} \mathrm{yr}^{-1}$ to $0.84 \mathrm{~m} \mathrm{yr}^{-1}$ in Hóladalsjökull. Kellerer-Pirklbauer et al. (2007) also studied the rock glacier dynamics in Fremri-Grjótárdalur and confirmed a velocity range from $0.06 \mathrm{~m} \mathrm{yr}^{-1}$ to $0.74 \mathrm{~m} \mathrm{yr}^{-1}$. Lilleøren et al. (2013) monitored the dynamics of various debris-covered and rock glaciers in the south of Hóladalur using techniques based on satellite radar interferometry (ALOS polarimetric PALSAR images between 16 August and 1 October 2007) and calculated velocities between 0.2-0.5 m yr ${ }^{-1}$, with maximum velocities exceeding $3 \mathrm{~m} \mathrm{yr}^{-1}$.

Tanarro et al. $(2015,2016)$ produce the comparison and visual recognition of the superficial landforms of the Fremri-Grjótárdalur rock glaciers and the Hóladalsjökull debris-covered glacier using georeferencing, contrasting a 1946 aerial photograph, a 2000 orthophoto and the 2013 image from Google Earth (Fig. 1, 5, 9 and 10). The results obtained reflect the almost total absence of changes in the surface morphology of the Hóladalsjökull debris-covered glacier. The main relief landforms such as ridges and furrows, both transversal and longitudinal, remain stable and immobile, with no appreciable readjustment or superficial deformation as might be expected of active glaciers over a 67 year period. Even the depressions from collapse observed in the 1946 image maintain identical morphologies in 2000 and in 2013. The appearance is only detected of a new depression from collapse in the 2000 image in the central sector. Similarly, no variations are observed in the glacier terminus or lateral ramps with the external limits remaining immobile (Tanarro et al., 2015, 2016). Similar results can be obtained from observing the images of the Fremri-Grjótárdalur rock glaciers. The western and more complex sector, where different bodies or lobes are juxtaposed, shows total stability, where the fronts of the different bodies, the crests transversal to the flow and the longitudinal grooves, generally snow-covered, maintain the same position at all the dates, with no appreciable deformation or morphological changes. In contrast, the eastern sector, formed by two main lobes, does seem to show some movement. In the upper lobe there is appreciable movement of its terminus with some deformation, while a slight change in the geometry of the lower lobe can be observed, changing from a more elongated shape where the front and transversal crests can be clearly seen in 1946, to an apparently more circular shape as the result of a slight collapse in 2000. From this date until 2013 no change was observed (Tanarro et al., 2015, 2016). 


\section{Fremri-Grjótárdalur}
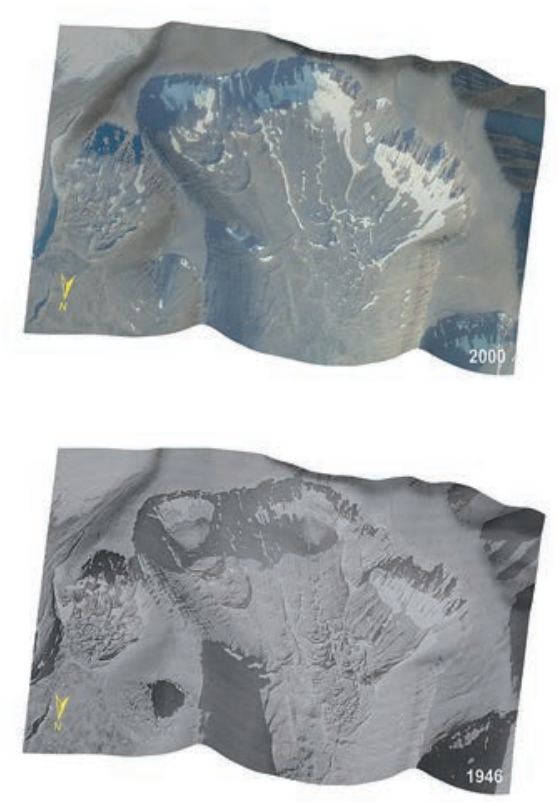

\section{Hóladalsjökull}

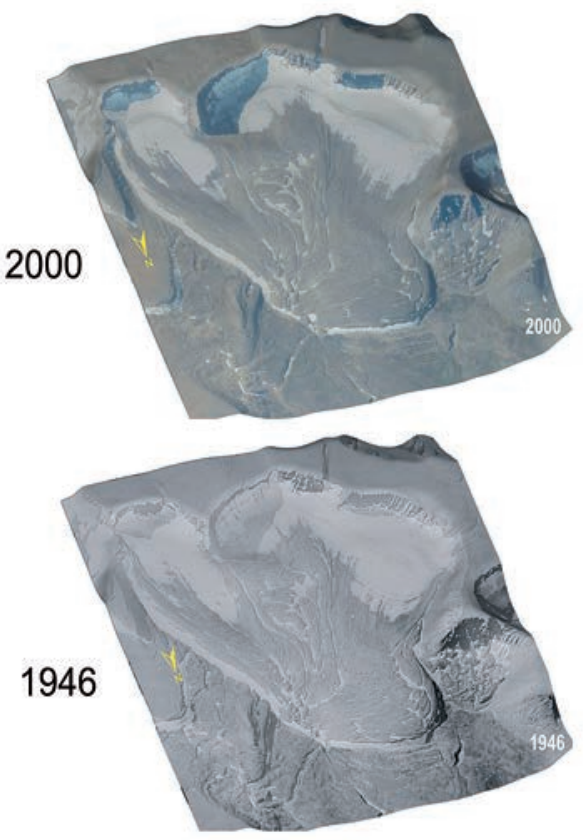

Figure 10. Fremri-Grjótárdalur rock glaciers and Hóladalsjökull debris-covered glacier ortophotos from 1946 and 2000, where no changes can be observed, according to Tanarro et al. $(2015,2016)$.

\section{Conclusions}

The alpine character of the Tröllaskagi Peninsula is the result of the confluence of a series of geographical and evolutive factors whose effects were noted from earlier studies and are now confirmed by more recent research.

Clearly, the main fundamental factor is the prolonged absence of volcanic activity, which has enabled the development of a deeply incised drainage network, forming valleys with vertical walls perpendicular to the fiords which delimit the peninsula, and in particular to emphasize the alpine character, valley heads in the form of cirques with vertical walls. However, the interfluves form flat summits, which are in fact large plateaux.

Another fundamental factor is its position with regard to the atmospheric circulation, in the lee of the great central volcanoes, which offer protection from the wet winds from the south and in fact transform the peninsula into a dry region. The lack of precipitation and the configuration of the relief prevent the formation of ice-caps on the summits, in contrast to what occurs in the Vestfirðir Peninsula, but allow the snow to accumulate in the cirques located downwind, i.e. those which are north-facing, swept by the wind from the great plateaux. 
In fact, there is no geomorphological evidence of ice-cap formation on the summits or that they were affected by the IIS at the end of the Pleistocene. Earlier and more recent research studies confirm both of these assertions. In addition, the presence of glaciers $2000 \mathrm{~m}$ longer than those currently found in the centre of Iceland would have allowed these mountains to exert a major role as an orographic barrier for Tröllaskagi. These features suggest the situation of Tröllaskagi as ice-free, delimited by two great glacier tongues flowing down from the IIS through the Skagafjödur and the Eyjafjödur fiords, at least since the Oldest Dryas. Although with successive recessions and advances, the termini of these huge glaciers would still have been present at the head of these fiords during the Early Preboreal.

In contrast, the advances of the Oldest, Older and Youngest Dryas and Early Preboreal would not have meant the formation of great glaciers in the tributary valleys of the Tröllaskagi fiords. On the contrary, these advances were only around a hundred metres longer than the greatest advance in the second half of the Holocene, which was the LIA, and therefore the glaciers did not lose their alpine character during the Late Pleistocene and Holocene.

Another important factor in the configuration of an alpine relief was the significant dynamism of the slopes. Their vertical character and the instability resulting from the alternating layers of lava and clays in the outcrops led to a succession of many types of enormous mass movements. Although much of Iceland was finally deglaciated around $11.4 \mathrm{ka}$, the tributary valleys of the Tröllaskagi Peninsula were deglaciated at least by the end of the LGM, if not before. Therefore the destructive mechanism of the glacial landforms by slope processes was much more prolonged, with more time available to conceal these landforms by a cover of aeolian deposits and tephras.

The Tröllaskagi glaciers have also evolved intimately related to the intensity of the slope processes, as occurs in alpine high mountain landscapes. Where the slope processes are slight or non-existent, the glaciers remain debris-free and demonstrate an enormous sensitivity to small climatic variations, with alternating 5-10 year warm or cold periods, retreating or advancing respectively. The results of research carried out on these glaciers since the mid- $20^{\text {th }}$ century to the present are in this context completely homogeneous.

Where the slope processes are intense, and large quantities of debris are deposited on the glaciers, these are transformed into debris-covered glaciers, if the proportion of debris is limited in relation to the ice mass, or into rock glaciers if the proportion of debris to ice mass is considerable. This diversity of the glaciers also facilitates the existence of a true alpine landscape. In this case, a wide variety of results can be seen in studies of the dynamics of these glaciers dominated by the factor of the insulating debris cover. But evidence of the total absence of geomorphological changes in this cover suggests the markedly static character of these formations. The absence of moraines at their termini, the existence of fossil rock glaciers since the Oldest Dryas, and the existence of erratic boulders of this age at the termini all support the idea that their origin and static nature is much older than suggested to date. 


\section{Acknowledgements}

This paper was funded by the CRYOCRISIS project (CGL2012-35858, Spanish Ministry of Economy and Competitiveness), Nils Mobility Program (EEA GRANTS) and with the help of the Research Group of High Mountain Physical Geography (Complutense University of Madrid). We thank to Icelandic Institute of Natural History, to Hólar University College, and to Icelandic Association for Search and Rescue (ICESAR) for their support in the field.

\section{References}

Andrews, J.T., Harðardóttir, J., Helgadóttir, G., Jennings, A.E., Geirsdóttir, Á., Sveinbjörnsdóttir, Á.E., Schoolfield, S., Kristjánsdóttir, G.B., Smith, L.M., Thors, K., Syvitski, J. 2000. The N and W Iceland Shelf: Insights into Last Glacial Maximum ice extent and deglaciation based on acoustic stratigraphy and basal radiocarbon AMS dates. Quaternary Science Reviews 19, 619-631.

Brynjólfsson, S., Ingólfsson, Ó., Schomacker, A. 2012. Surge fingerprinting of cirque glaciers at the Tröllaskagi Peninsula, North Iceland. Jökull 62, 1-16.

Brynjólfsson, S., Schomacker, A., Ingólfsson, Ó. 2014. Geomorphology and the little ice age extent of the Drangajökull ice cap, NW Iceland, with focus on its three surge-type outlets. Geomorphology 201, 292-304.

Brynjólfsson, S., Schomacker, A., Ingólfsson, Ó., Keiding, J.K. 2015a. Cosmogenic 36Cl exposure ages reveal a $9.3 \mathrm{ka}$ BP glacier advance and the Late Weichselian-Early Holocene glacial history of the Drangajökull region, northwest Iceland. Quaternary Science Reviews 126, 140157.

Brynjólfsson S., Schomacker, A., Guðmundsdóttir, E.R., Ingólfsson, Ó. 2015b. A 300-year surge history of the Drangajökull ice cap, northwest Iceland, and its maximum during the 'Little Ice Age'. The Holocene 25, 1076-1092.

Caseldine, C.J. 1983. Resurvey of the Margins of Gljúfurárjökull and the Chronology of recent Deglaciation. Jökull 33, 111-118.

Caseldine, C. 1985. The extent of some glaciers in Northern Iceland during the Little Ice Age and the nature of recent deglaciation. Geographical Journal 151, 215-227.

Caseldine, C.J. 1987. Neoglacial glacier variations in Northern Iceland: examples from the Eyjafjördur area. Arctic and Alpine Research 19, 296-304.

Caseldine, C.J., Cullingford, R.A. 1981. Recent Mapping of Gljúfurárjökull and Gljúfurárdalur. Jökull 31, 11-22.

Caseldine, C., Hatton, J. 1994. Interpretation of Holocene Climatic Change for the Eyjafjördur Area of Northen Iceland from Pollen-Analytical data: Comments and Preliminary results. In: J. Stöner, F. Wilhelm, F. (eds.), Environmental Changes in Iceland. Münchener Geographische Abhandlungen, Reihe B. Band B12, 41-62.

Caseldine, C., Stötter, J. 1993. 'Little Ice Age' glaciation of Tröllaskagi Peninsula, northern Iceland: climatic implications for reconstructed equilibrium line altitudes (ELAs). The Holocene 3, 357-366.

Caseldine, C., Geirsdottir, A., Langdon, P. 2003. Efstadalsvatn - a multiproxy study of a Holocene lacustrine sequence from NW Iceland. Journal of Paleolimnology 30, 55-73.

Caseldine, C., Langdon, P.G., Holmes, N. 2006. Early Holocene climate variability and the timing and extent of the Holocene thermal maximum (HTM) in northern Iceland. Quaternary Science Reviews 25, 2314-2331. 
Coquin, J., Mercier D., Bourgeois, O., Cossart E., Decaulne A. 2015. Gravitational spreading of mountain ridges coeval with Late Weichselian deglaciation: impact on glacial landscapes in Tröllaskagi, northern Iceland. Quaternary Science Reviews 107, 197-213.

Cossart, E., Mercier, D., Decaulne, A., Feuillet, T., Jónsson, H.P., Sæmundsson, p. 2014. Impacts of post-glacial rebound on landslide spatial distribution at a regional scale in northern Iceland (Skagafjörður). Earth Surface Processes and Landforms 39, 336-350.

Einarsson, M.A. 1976. Vedurfar á Islandi. Idunn. Reykjavik, 150 pp.

Einarsson, M.A. 1991. Temperature conditions in Iceland 1901-1990. Jökull 41, 1-20.

Einarsson, Th. 1963. Pollen-analitical studies on vegetation and climate history of Iceland in late and post-glacial times. In: A. Löve, D. Löve (eds.), North Atlantic biota and their history, Pergamon, 355-365.

Einarsson, Th. 1966. Late and Post-glacial rise in Iceland and sub-crustal viscosity. Jökull 16, 157-166.

Einarsson, Th. 1967. Zu der ausdehnung der weichselzeitlichen vereisung Nordislands. Sonderveröffentlichungen des Geologischen Institutes der Universität Köln 13, 167-173.

Einarsson, Th. 1973. Geology of Iceland. In: M.G. Pitcher (ed.) Artic geology. American Association of Petroleum Geologists Memoir 19, 171-175.

Etzelmüller, B., Farbrot, H., Guðmundsson, Á., Humlum, O., Tveito, O.E., Björnsson, H. 2007. The regional distribution of mountain permafrost in Iceland. Permafrost and Periglacial Processes 18, 185-199.

Eythorsson, J. 1935. On the variations of glaciers in Iceland, some studies made in 1931. Geografiska Annaler 1-2, 121-137.

Farbrot, H., Etzelmüller, B., Schuler, T.V., Guðmundsson, Á., Eiken, T., Humlum, O., Björnsson, H. 2007. Thermal characteristics and impact of climate change on mountain permafrost in Iceland. Journal of Geophysical Research 112: F03S90.

Fernández, J.M., Andrés, N., Tanarro, L.M., Palacios, D. 2015. Glacial and climatic evolution from the Little Ice Age last Maximum to the present in Tröllaskagi Peninsula (North Iceland): the case of Gljúlfurárjökull. Geophysical Research Abstracts Vol. 17, EGU2015-13719.

Fernández, J.M., Andrés, N., Tanarro, L.M., Sæmundsson, P., Palacios, D. (2016). High sensitivity of debris free glaciers to climatic change in Tröllaskagi Peninsula (North Iceland). The Holocene (Submitted).

Feuillet, T., Coquin, J., Mercier, D., Cossart, E., Decaulne, A., Jónsson, H.P., Sæmundsson, p., 2014. Focusing on the spatial non-stationarity of landslide predisposing factors in northern Iceland: do paraglacial factors vary over space? Progress Physical Geography 38, 354-377.

Geirsdóttir, A. 2011. Pliocene and Pleistocene Glaciations of Iceland: A Brief Overview of the Glacial History. In: J. Ehlers, P.L. Gibbard, P.D. Hughes (eds.), Quaternary Glaciations Extent and Chronology. Amsterdam, ISBN 978-0-444-53447-7, pp. 199-210.

Geirsdóttir, Á., Andrews, J.T., Ólafsdóttir, S., Helgadóttir G., Harðardóttir J. 2002. A 36 Ky record of iceberg rafting and sedimentation from north-west Iceland. Polar Research 21, 291-298.

Geirsdóttir, A., Miller, G.H., Axford, Y., Ólafsdóttir, S., 2009. Holocene and latest Pleistocene climate and glacier fluctuations in Iceland. Quaternary Science Reviews 28, 2107-2118.

Geirsdóttir, A., Miller, G.H., Larsen, D.J., Ólafsdóttir, S. 2013. Abrupt Holocene climate transitions in the northern North Atlantic region recorded by synchronized lacustrine records in Iceland. Quaternary Science Reviews 70, 48-62.

Häberle, T. 1991. Holocene glacial history of the Hörgádalur area, Tröllaskagi, northern Iceland. In: J.K. Maizels, C. Caseldin (eds.), Environmental change in Iceland: Past and present, Kluwer, Dordrecht, pp. 193-202. 
Häberle, T. 1994. Glacial, Late Glacial and Holocene history of the Hörgádalur area, Tröllaskagi, Northern Iceland. In: J. Stötter, F. Wilhelm (eds.), Environmental change in Iceland, Münchener Geographische Abhandlungen, Vol. B12, pp. 133-145.

Hamilton, S.J., Whalley, W.B. 1995. Preliminary results from the lichenometric study of the Nautárdalur rock glacier, Tröllaskagi, northern Iceland. Geomorphology 12, 123-132.

Hole, I. 2015. Glacial geomorphology and Late Quaternary glacial History of Hornstrandir, NW Iceland. Unpublished thesis. Norwegian University of Science and Technology, Trondheim, $96 \mathrm{pp}$.

Hubbard, A., Sugden, J. Dugmore, A., Norðdahl, H., Pétursson, H.G. 2006. A modelling insight into the Icelandic Late Glacial Maximum ice sheet. Quaternary Science Reviews 25, 22832296.

Ingólfsson, O. 1991. A review of the late Weichselian and early Holocene glacial and environmental history of Iceland. In: J. Maizels, C. Caseldine (eds.), Environmental Change in Iceland: Past and Present, Kluwer Academic Publishers, Dordrecht, pp. 13-29.

Ingólfsson, O., Norðdahl, H. 1994. A review of the environmental history of Iceland, 13000-9000 yr BP. Journal of Quaternary Science 9, 147-150.

Ingólfsson, Ó., Björck, S., Hafliðason, H., Rundgren, M. 1997. Glacial and climatic events in Iceland reflecting regional North Atlantic climatic shifts during the Pleistocene-Holocene transition. Quaternary Science Reviews 16, 1135-1144.

Jönsson, Ó. 1976. Berghlaup. Raektunarfélag Norðurlands. Akureyri, 623 pp.

Kaldal, I., Víkingssson, S. 1990. Early Holocene Deglaciation in Central Iceland. Jökull, 40, 5166.

Kellerer-Pirklbauer, A., Wangensteen, B., Farbrot, H., Etzelmüller, B. 2007. Relative surface age-dating of rock glacier systems near Hólar in Hjaltadalur, northern Iceland. Journal of Quaternary Science 23, 137-151.

Kirkbride, M.P., Dugmore, A.J. 2001. Timing and significance of mid-Holocene glacier advances in northern and central Iceland. Journal of Quaternary Science 16, 145-153.

Kirkbride, M.P., Dugmore, A.J. 2006. Responses of mountain lee caps in central Iceland to Holocene climate change. Quaternary Science Reviews 25, 1692-1707.

Kugelmann, O. 1991. Dating recent glacier advances in the Svarfaðardalur-Skiðadalur area of northern Iceland by means of a new lichen curve. In: J. Maizels, C. Caseldine (eds.), Environmental change in Iceland: Past and present, Kluwer Academic Publishers, Dordrecht, pp. 203-217.

Larsen, D., Miller, G.H., Geirsdottir, A., Ólafsdóttir, S. 2012. Non-linear Holocene climate evolution in the North Atlantic: a high-resolution, multi-proxy record of glacier activity and environmental change from Hvítárvatn, central Iceland. Quaternary Science Reviews 39, 1425.

Lilleøren, K.S., Etzelmüller, B., Gärtner-Roer, I., Kääb, A., Westermann, S., Guðmundsson, Á. 2013. The distribution, thermal characteristics and dynamics of permafrost in Tröllaskagi, Northern Iceland, as inferred from the distribution of rock glaciers and ice-cored moraines. Permafrost and Periglacial Processes 24, 322-335.

Martin, E., Whalley, W.B., Caseldine, C. 1991. Glacier fluctuations and rock glaciers in Tröllaskagi, Northen Iceland, with Special reference to 1946-1986. In: J. Maizels, C. Caseldine (eds.), Environmental change in Iceland: past and present, Kluwer Academic Publishers, Dordrecht, pp. 255-264.

Martin, E., Whalley, W.B., Orr, J, Caseldine, C. 1994. Dating and interpretation of rock glaciers using lichenometry, south Tröllaskagi, North Iceland. Münchener Geographische Abhandlungen B 12, 205-224. 
Martin, E., Whalley, W.B. 1987. A glacier ice-cored rock glacier, Tröllaskagi, Iceland. Jökull 37, 49-56.

Mercier, D., Cossart, E., Decaulne, A., Feuillet, T., Jónsson, H.P., Sæmundsson, p. 2013. The Höfðahólar rock avalanche (sturzström): chronological constraint of paraglacial landsliding on an Icelandic hillslope. The Holocene 23, 432-446.

Norðdahl, H. 1991a. Late Weichselian and early Holocene deglaciation history of Iceland. Jökull $40,27-50$.

Norðdahl, H. 1991b. A review of the glaciation maximum concept and the deglaciation of Eyjafjordur, North Iceland. In: J. Maizels, C. Caseldine (eds.), Environmental Changes in Iceland: Past and Present, Kluwer Academic Publishers, Dordrecht, pp. 31-47.

Norðdahl, H., Einarsson, Th. 2001. Concurrent changes of relative sea-level and glacier extent at the Weichselian - Holocene boundary in Berufjörður, Eastern Iceland. Quaternary Science Reviews 20, 1607-1622.

Norðdahl, H., Pétursson, H.G. 2005. Relative sea level changes in Iceland. New aspects of the Weichselian deglaciation of Iceland. In: C. Caseldine, A. Russel, J. Harðardottir, Ó. Knudsen (eds.), Iceland - Modern Processes and Past Environments, Elsevier, Amsterdam, pp. 25-78.

Norðdahl, H., Ingólfsson, Ó., Pétursson, H.G., Hallsdóttir, M. 2008. Late Weichselian and Holocene environmental history of Iceland. Jökull 58, 343-364.

Palacios, D., Andrés, N., Sæmundsson, P., Brynjólfsson, S. 2015. The deglaciation of the Tröllaskagi Peninsula, Northern Iceland, based oncosmogenic datings. Geophysical Research Abstracts Vol. 17, EGU2015-9648.

Palacios, D., Andrés, N., Sæmundsson, P., Brynjólfsson, S. (2016). The deglaciation of the Tröllaskagi Peninsula (North Iceland). Quaternary Science Reviews (Submitted).

Pétursson, H.G., Norðdahl, H., Ingólfsson, O. 2015. Late Weischelian history of relative sea level changes in Iceland during a collapse and subsequent retreat of marine based ice sheet. Cuadernos de Investigación Geográfica 41 (2), 261-277.

Principato, S.M., Geirsdottir, A., Johannsdottir, G.E., Andrews, J.T. 2006. Late Quaternary glacial and deglacial history of eastern Vestfirdir. Journal of Quaternary Science 21, 271-285.

Principato, S.M. 2008. Geomorphic evidence for Holocene glacial advances and sealevel fluctuations on eastern Vestfirdir, northwest Iceland. Boreas 37, 132-145.

Principato, S., Johnson, J.S. 2009. Using a GIS to quantify patterns of glacial erosion on northwest iceland: implications for independent ice sheets. Arctic, Antarctic and Alpine Research 41, 128-137.

Rundgren, M. 1995. Biostratigraphic evidence of the Allerød-Younger Dryas-Preboreal oscillation in Northern Iceland. Quaternary Research 44, 405-416.

Rundgren, M. 1999. A summary of the environmental history of the Skagi Peninsula, northern Iceland, 11,300-7800 BP. Jökull 47, 1-19.

Rundgren, M., Ingólfsson, Ó. 1999. Plant survival in Iceland during periods of glaciations. Journal of Biogeography 26, 387-396.

Sigbjarnasson, G. 1983. The Quaternary alpine glaciation and marine erosion in Iceland. Jökull $33,87-98$.

Sigurvinsson, J.R. 1983. Weichselian glacial lake deposits in the highlands of Northwestern Iceland. Jökull 33, 99-109.

Steindórsson, S. 1963. Ice age refugia in Iceland as indicated by the present distribution of plant species. In: A. Löve, D. Löve, (eds.), North Atlantic biota and their history, Pergamon, pp. 87-98.

Stötter, J. 1991. New observations on the postglacial glacial history of Tröllaskagi, northern Iceland. In: J. Maizels, C., Caseldine (eds.), Environmental change in Iceland: Past and present, Kluwer, Dordrecht, pp. 181-192. 
Stötter, J., Wastl, M., Caseldine, C., Häberle, T. 1999. Holocene palaeoclimatic reconstructions in Northern Iceland: approaches and results. Quaternary Science Reviews 18, 457-474.

Tanarro, L.M., Palacios, D., Andrés, N., Fernández, J.M. 2015. Static debris-covered glaciers and rock glaciers in Tröllaskagi Peninsula (northern Iceland): The cases of Hóladalur and FremriGrjótárdalur. Geophysical Research Abstracts Vol. 17, EGU2015-11547.

Tanarro, L.M., Fernández, J.M., Andrés, N., Zamorano, J.J., Palacios, D. (2016). Unchanged surface morphology of debris-covered glaciers and rock glaciers in Tröllaskagi Peninsula (northern Iceland). Geomorphology (Submitted).

Thórarinsson, S. 1937. The main geological and topographic features of Iceland. Geografiska Annaler 19, 161-175.

Veit, H., Marti, H., Winiger, L. 2011. Environmental changes in Northern Iceland since the Younger Dryas inferred from periglacial slope deposits. The Holocene 22 (3), 325-335.

Wangensteen, B., Guðmundsson, Á., Eiken, T., Kääb, A., Farbrot, H., Etzelmüller, B. 2006. Surface displacements and surface age estimates for creeping slope landforms in Northern and Eastern Iceland using digital photogrammetry. Geomorphology 80, 59-79.

Wastl, M., Stötter, J. 2005. Holocene glacier history. In: C. Caseldine, A. Russell, J. Hardardóttir, O. Knudsen (eds.), Iceland - Modern Processes and Past Environments. Developments in Quaternary Sciences 4, Elsevier, Amsterdam, pp. 221-240.

Wastl, M., Stötter, J., Caseldine, C. 2001. Reconstruction of Holocene variations of the upper limit of tree or shrub birch growth in northern Iceland based on evidence from VesturardalurSkiðadalur, Tröllaskagi. Arctic, Antarctic and Alpine Research 33, 191-203.

Whalley, W.B., Martin, H.E. 1994. Rock glaciers in Tröllaskagi: their origin and climatic significance. In: J. Stötter, F. Wilhelm (eds), Environmental Change in Iceland, Münchener Geographische Abhandlungen B 12, pp. 289-308.

Whalley,W.B., Hamilton, S.J., Palmer, C.F., Gordon, J.E., Martin, H.E. 1995a. The dynamics of rock glaciers: data from Tröllaskagi, north Iceland. In: O. Slaymaker (ed). Steepland geomorphology, John Wiley \& Sons Ltd., Chichester, pp. 129-146.

Whalley, W.B., Palmer, C.F., Hamilton, S.J., Martin, H.E. 1995b. An assessment of rock glacier sliding using seventeen years of velocity data: Nautárdalur Rock Glacier, North Iceland. Arctic and Alpine Research 27 (4), 345-351. 